\title{
Kostskolerne i Christiansfeld.
}

Af Sognepræst Dr. theol. Jens Foldt.

I.

\section{Indledning. Historisk Oversigt.}

Barnesindet er den modtagelige Muld, der forjætter Udsædens rigeste Høst. I Barneaarene fastlægges Menneskers og dermed ogsaa Folkenes senere Livsholdning. Den, der vil Fremtiden, maa derfor vinde Ungdommen og lære de unge Vejen, hau ønsker de skal gaa. Han maa paatage sig Undervisningens og Opdragelsens store og skønne Opgave, det Saa-Arbejde i aabne Barnesind, som er Hjemmets fornemste Hverv her i Livet.

$K$ r i s t u s bød, at de smaa Børn skulde komme til ham, for at han kunde velsig $\mathrm{n}$ e dem. Sine Lærlinge gav han den Anvisuing, at de skulde $1 \ngtr \mathrm{r}$ e de Folkeslag, de døbte til hans Navn, Kristendommens store Kærlighedsbud.

Om P a u l u s, Oldkirkens store Missionær, hører vi, at han $i$ de af ham missionerede Middelhavslande indsatte unge Mænd, der skulde føre hans Missionsgerning videre paa Stedet. Om A n s a r, Nordens Apostel, berettes det, at han samlede danske Drenge omkring sig, og lærte dem det kristne Budskab, for at de saa kunde bringe det videre til deres Landsmænd.

Christiansfelds Grundlægger (1773), den svenskfødte Hugenot-Atling $\mathrm{J}$ on a $\mathrm{t}$ h a n B r i a $\mathrm{t}$, var klar over, at han maatte gaa samme Vej, om han skulde skaffe Herrnhutismen videre Indgang i Nordens Lande. Selv havde han i sine egne Lære-Aar virket ved Brødremenighedens Opdragelses-Instituter i Tyskland. Saasnart Forholdene i den ny anlagte Herrnhuter-Koloni her paa Grænsen mellem Nord- og Sønderjylland gjorde det forsvarligt, gik han i Gang med Oprettelsen af en Kostskole paa Stedet, med en Afdeling for Drenge og en for Piger. BrødreVennerne i Oplandet, omfattende hele Skandinavien, var blevne underrettede i Forvejen og havde givet Tilsagn om, sax vidt gør- 
ligt at ville sende deres Born til de nye Opdragelses-Instituter i Christiansfeld, den nygrundlagte "Guds By i i Norden.

Allerede 1775, den 4. Januar, begyndte Drenge-Skolen med Præstesønnerne Johannes og Christian Ewald fra Hviding som de første Elever. En Maanedstid senerc, den 15. Februar, aabnedes Pige-Skolen med Elisabeth Fabricius fra Humptrup Præstegaard og Margrethe Isager fra Vestjylland. I Aarets Løb kom flere til. Og Tilgangen voksede derefter jævnt Aar for Aar op imod Aarhundredskiftet. Fra alle Nordens tre Lande sendtes Børn til Undervisning og Opdragelse i Christiansfeld. I 1790erne var man oppe paa det højeste Tal, som nogensinde naaedes, nemlig godt og vel 100 Kost-Elever.

Drenge-Skolen var til at begynde med anbragt i Brødre-Huset, og Pige-Skolen i det foreløbige Menigheds-Hus. Men det hurtigt voksende Elev-Tal krævede ret omgaaende udvidede og forbedrede Lokaler baade til Undervisning og Logis. 1784 fik PigeAfdelingen sin egen nye Bygning, efter at den fra 1780 havde haft til Huse i Enke-Huset. Drenge-Afdelingen drog 1788 ind i sin store Nybygning, der allerede 1796 maatte udvides yderligere. Nye Lokale-Forbedringer kom til, efter som Tiden krævede dem. Gymnastiksal byggedes 1862 .

Men Skolernes Vækst i Koloniens første Blomstringstid forlangte $i$ første Linie en gennemført Organisation af selve Undervisningen og hele Omsorgen for de Menigheden betroede Børn. Der oprettedes derfor (1780) et Inspek tør-E mbede ved Skolerne, og lidt senere (1785) yderligere et særligt $\mathrm{H} \mathrm{u}$ s f ad er-E m b e d e, som besattes med et Agtepar, der - i Forældrenes Sted - skulde drage Omsorg for Elevernes hele legemlige og sjælelige Vel, gøre det hjemligt for dem og danne Forbindelsesleddet til deres Hjem. Siden (1810) forenedes de to Embeder igen til ét, Skole-Lederens, der skulde værə gift. $\left.{ }^{1}\right)$

Kostskolerne opretholdtes det 19. Aarhundrede igennem indtil 1891, da de ophævedes paa Grund af manglende Pensio-

1) Særlige Husfædre var: 1785-89 David Zimmer, 1789-1804 Carl Gottlieb Dietrich, 1804-10 Christoph Senft, alle indkaldte Tyskere. 
nærer udefra. Man fortsatte saa med almindelig Dag-Skole indtil 1920, da Skole-Undervisningen paa Stedet blev opgivet af Brødremenigheden og gik over paa private Hænder. ${ }^{2}$ )

Skolernes Trivsel var i dette forholdsvis lange Tidsrum i mangt og meget afhængig af de skiftende ydre Tidsomstændigdigheder. Da det 18. Aarhundredes Freds- og Lykke-Tid i Norden med Begyndelsen af det nye 19. Aarhundrede aflestes af Krigs- og Nødstider for vort Land, der med kortere eller længere Mellemrum kom til at præge hele dette Aarhundrede, maatte Skolerne i Christiansfeld ogsaa tage deres Part af Tidens Skæbne. Napoleonskrigene i de forste to Aartier med Dyrtiden i Følge mindskede, ja standsede en Overgang Tilgangen helt fra Sverige og Norge og hæmmede den betydeligt fra Danmark. Dertil kom, at Statens Forbedringer af det officielle Skolevæsen i Begyndelsen af Aarhundredet - en Frugt af det 18. Aarhundredes Oplysnings-Bestræbelser - svækkede Trangen til at sende Børnene saa langt hjemmefra. Den hermed sammenhængende folkelige Vækkelse og vaagnende nationale Bevidsthed $\mathbf{i}$ Romantikkens Tidsalder virkede i samme Retning. 1831 var man af de her nævnte Aarsager nede paa kun 13 Elever ude fra, foruden Dag-Eleverne. Siden øgedes Tilgangen udefra igen betydeligt, men blev - i Forbindelse med Bismarck-Krigene igen udsat for stærke Svingninger, der især gjorde sig gældende efter Statsskiftet 1864. Antallet af Pensionærer aftog herefter jævnt, medens til Gengæld Tallet paa kun skolesøgende Elever baade fra selve Byen og fra Omegnen tiltog i stigende Grad.

Selvom Skolens udtalt kristne Grundsigte hele Tiden igennem forblev det samme, og Undervisningen i Kristendom stadig var det bærende Fag, kunde det ikke undgaas, at de politiske Omskiftelser kom til at ove deres Indflydelse paa Skolens Program. Et fremtrædende Punkt i dette havde hele Tiden været, at Eleverne her - ved Siden af almindelig Sprog-Undervisning - især grundigt kunde lære det tyske Sprog. Men efter

$\left.{ }^{2}\right)$ Den nuværende private Realskole, der af Brødremenigheden har lejet de gamle Skolelokaler. 
1864 betragtede Skolens Ledelse sig fuldt ud som staaende i selve Tyskhedens Tjeneste i Grænselandet. Kolonien Christiansfeld betragtedes af Bismarcks Preussen som en værdifuld tysk Bastion ved den nye Statsgrænse mod Nord og fandt tilsvarende Øvrighedsgunst. Denne germaniserende Indstilling, der ikke havde været understreget under dansk Statsstyre i den forudgaaende Tid siden Grundlæggelsen, lukkede selvfølgelig i høj Grad af for Tilgangen fra Nord. En vis Erstatning herfor bragte en forbigaaende Sogning af engelske Elever.

Af særlige Begivenheder i Skolens Historie kan nævnes Jubilæums-Festlighederne i $1825 \mathrm{og} 1875$. Begge gav en velkommen Anledning til ny Hvervning. I 1825 forfattedes en Jubilæumskantate, der blev sunget ved Festlighederne og sendt til forhenværende Elever. Der havde i de første 50 Aar da været 988 Elever, 790 udefra og 198 fra selve Byen! Nævnes skal endvidere ikke saa faa Besøg af den danske Konge og andre Medlemmer af Kongehuset, naar de var paa Gennemrejse mellem Kongeriget og Hertugdømmerne. ${ }^{3}$ ) Ogsaa den svenske Konge standsede en enkelt Gang i Christiansfeld (1805) og lod sig Byen og dens Indretninger forevise. Et ubehageligt Minde blev Kosakkernes Besættelse af Byen under Tettenborn 7.-16. Januar 1814; men man slap dog naadigt, efter at Inspektor Sønnichsen havde forevist Byen for Generalen. Muligvis har denne i Forvejen haft et fordelagtigt Kendskab til Brødrekolonien Sarepta, grundlagt 1767 ved Volga-Knæet i Sydrusland, en sydlig Forstad til det nuværende Stalingrad. Under de slesvigske Krige var der jævnligt Indkvarteringer i Byens rummelige Lokaler. Kirkesalen blev brugt som Lazaret.

Fra Tid til anden blev Skolerne hjemsøgt af epidemiske Børnesygdomme, der voldte megen $A$ Engstelse og Bekymring hos Lederne, og ikke mindre hos Forældrene hjemme, der dog lod sig

3) Arveprins Frederik 1785 og 93, Kronprins-Regenten 1787, 90, 9:, 94, 96, 99. (Illumination 1794 og 96); Fr. VI. 1809 og 1831; Kronprinsen 1838; Chr. VIII. 1840 og 43; Fr. VII. 1858 
berolige ved at vide deres Børn i moderlige Hænder paa Stedet. Mest smerteligt var det naturligvis, naar der indtraadte ot Dødsfald blandt Eleverne, hvilket hændte adskillige Gange i den første Tid. (16 indtil 1825). Men ogsaa i dette Tilfælde maatte man give sig tilfreds i Troens Forvisning om, at Barnet nu fra Forgaarden i Menigheden var hentet ind i Himlens Helligdom.

II.

\section{Skolens Ledere.}

Ved Siden af de ydre Vilkaar, som Skolen maatte tage og bære med større eller mindre Held, var dens Trivsel og gode Rygte naturligvis ogsaa i høj Grad afhængig af de Mænd og Kvinder, der stod med Ansvaret for Undervisningen og Opdragelsen i Institutet. Det er uoverkommeligt at nævne alle Lærernes og Lærerindernes Navne, der her i Aarenes Lab har ovet en faglig og personlig Indsats. Jeg skal indskrænke mig til forst at give en skematisk Oversigt over Lederne gennem hele Tidsrummet, ${ }^{4}$ ) for derefter at omtale et Par fra den danske Tid noget udførligere.

1775-77: D avid Piesch, 1742 London-1798 Barby, Elev paa Brødremenighedens Skoler i Marienborn, Lindheim, Barby og Gross Hennersdorf, Lærer i Niesky og Amsterdam, - siden i Barby.

1777-80: Georg Jacobsen Wemmenhøy, 1713 Odense 1788 Christiansfeld, Søn af Raadsherre, 1734 Student ved Københavns Universitet, Ophold i Norge og Lifland, 1781 pensioneret.

1780-85: Johann Christian Beatus Neumann, 1750 Meerholtz, Thüringen - 1816 Sarepta, Brødrekoloni ved Volga-Knæet i Syd-Rusland. Elev paa Brødremenighedens Pædagogium i Niesky og Seminarium i Barby, - siden i Herrnhut og Lifland.

1785-86: Friedrich Benjamin Reichel, 1759 Neukirch, Sachsen - 1835 Königsfeld. Præstesøn, Elev Niesky og Barby, 1785 Medhjælper Christiansfeld, - siden: 1792 Protokolfører ved U. A. C., (Unitets Aeldste Conferens), 1797 Præst Ebersdorf, 1800 Neuwied, 1807 Ebersdorf, 1816 Basel. 1818 Sarepta (Biskop), 1825 Königsfeld.

1786-94: D a vid S ch iffert, 1758 Königsberg - 1814 Niesky. Kabmandssøn, 1776 Elev i Barby, Lærer Gnadenfrei, Schlesien, 1781

4) Jfr. Oversigten i Christiansfeld Realskoles Elev-Aarsskrift 1936 og 37 . 
Førstelærer Chrfld., - siden: 1794 Præst Haarlem, Holland, 1799 Uhyst, 1801 Altona, 1810 Kbhvn.

1794-1801: Joh a n nes Nielsen, 1763 Kiel - 1814 Neusalz, Schlesien. Gennemgik fra 3 Aars Alderen Brødremenighedens forskellige Anstalter, Lærer Niesky, Uhyst og Chrfld, - siden: Præst Norden, Holland, Altona o.g Nsalz.

1801-04 og 1810-32: Søn i ch Søn i chsen, 1770 Hellevad, Aabenraa Amt - 1852 Hrnht. 1780 .Elev i Chrfld., 84 Niesky, 89 Barby, 93 Lærer Niesky, 97 Chrfld., - 1804-10 og 1832-43 Protokolfører ved U. A. C.

1804-1807 og 1809-10: P e ter Tresch ow, 1760 Drammen -1827 Nwied. Køibmandssøn, Broder til Filosoffen Niels T.. 1786 Elev i Zeist, 1774 INiesky, Lærer Zeist og Barby, 1789 Præst Amsterdam, 92 Forstander Kbhvn., 99 Præst Chrfld., 1811 Zeist, 1817 Agent for det britiske Bibelselskab og Israelsmissionen i London, 1825 Præst Nwied.

1807-09: C h ristian Ferdinand W underling, 1777 Halberstadt - 1850 Gnadenfrei. Lærersøn, 1795 Student i Halle, 97 Lærer Uhyst, 1801 Barby, 0a Niesky, - siden 1809 Medhjælper Hrnht., 11 Stockholm, 14 Præst Chrfld, 18 Gnadau, 25 Gnfrei.

1832-51: P hilip J a c ob Roentgen, 1777 Nwied -- 1855 Königsherg. Fader Mabelfabrikant, 91 Elev i Barby, 95 Niesky, 89 Lærer Nwied, 1803 Protokolfører ved U. A. C., 04 Præst og Inspektør Gnfld., 18 .Nwied, 27 Chrfld., 51 Königsberg.

1851-59: P e te r N y b or g Hess e l ber g, 1804 Kbhvn. -- 1859 Chrfld. Præstesøn, 1834 Lærer Chrfld., 40 Medhjælper Ehersdorf og Nwied, 46 dansk Præst og Medinspektør Chrfld.

1859-68: C a r l L u d w i g H e r m a n n v. B ü l o w, 1820 Rathenau - 1898 Niesky. 1828 Elerv i Gnfrei, 31 Niesky, 56 Stockholm, - siden: 1868-82 Inspektør Kleinwelka.

1868-73: Arthur Guid o Burkhardt, 1832 Niesky - 1903 Hrnht.. Apotekersøn, 1844 Elev i Niesky, 50 Gnfld., 53 Lærer Ebersdorf og Niesky, 59 Docent Gnfld., — siden: 1873 Inspektør Königsfld., 81 Præst Berlin, 86 Neudietendorf, 86 Missionsdirektør Berthelsdorf, 9i pensioneret.

1863-76: C a r l ot to Le op o I d G arve, 1834 Altona - 1902 Kassel. Præstesøn, 1856 Lærer Lausanne, 58 Ebersdorf, 62 Nwied, 65 Inspektør Königsfld., 70 Missionær paa Barbados, - siden: i Zeist, Berlin og Ndietendorf.

1876-82: Emmanuel Gustav Hentschel, 1823 Königsberg - 1884 Goldberg, Schlessien. Søn af Societetsarbejder. Elev i Niesky og Gnfld., Lærer Königsfld., Chrfld., og Gnberg, Societetsarbejder Strasbourg, Præst Haarlem og Ebersdorf.

1882-93: Friedrich Ernst Mory, 1842 Niesky - 1908 Ebersdorf. Elev i Niesky, Lærer Nwied, Medhjælper Hrnht., Soc.-Arbejder Danzig, - siden Forstander Berlin. 
1893-99: J o hannes Martin Burkhard t, 1858 Göteborg 1913 Hrnht. Søn af Soc.-Arbejder, Elev i Klwelka og Niesky, Lærer Gnfld. og Niesky, 1889 Medhjælper Chrfld. - siden: Præst Gnadau, 1901 Inspektør Nwied.

1899-1901: M a x M o r i z Me y er, 1860 Ober Peilau, Schlesien - 1942 Mocker, Schlesien. Køilumandssøn, Elev i Niesky og Gnfld., Lærer Königsfld., - siden: Præst Nsalz, 1906 Diaspora-Arbejder i Warthebruch, 10 Medhjælper Ebersdorf, 12 Soc.-Arbejder Görlitz, 28 pensioneret.

1901-12: Carl Johannes William Breute 1, 1865 Haarlem - 1941 Nwied. Præsitesøn, Elev i Strasbourg, Niesky og Gnfld., 1888 Lærer Chrfld., 93 Niesky og Gnadau, - siden: 1911 Præst Chrfld., 12 Basel, 19 Berlin, 34 pensioneret.

1912-20: Al ex and er v. D ew it z, 1870-1929 Ebersdorf, 1899 Lærer Klwelka, Nwied og Niesky. Missionær Syd Afrika, - siden: Inspektør Gnfrei og Præst Hausdorf. -

Af de ovennæevnte Skoleledere skal nu et Par fra den danske Tid lidt nærmere omtales, to af dem mere udførligt.

$\mathrm{N}$ e u m a n $\mathrm{n}$ var den første egentlige Inspektør. Han havde dog et svageligt Helbred, saa den, der maatte bære Arbejdet, har været Førstelæreren $S \mathrm{ch}$ if f er t, der siden blev hans Efterfølger. Han var Østpreusser og synes at have været en dygtig og energisk Skolemand, der bl. a. arbejdede med Udgivelsen af Skolebøger og $\mathrm{i}$ det hele satte Undervisningen $\mathrm{i}$ god Gænge. Men Skolegerningen har for ham som for de fleste andre yngre Mænd i Embedet været et Gennemgangsled til Præstegerningen. Hans Afløser, $\mathrm{N}$ i elsen, var fra Kiel, Søn af en velhavende hermhutisk Tobaksfabrikant, formodentlig Slesviger af Fødsel. Han havde aabenbart gode Evner, men tillige en lidt ustadig Karakter. Ogsaa han gik efter Lære-Aarene i Skolen ind i Præstegerningen.

Først med Søn n c h Søn n i chsen, født den 11. Oktober 1770 paa Hellevad Vandmølle, $15 \mathrm{~km}$ Vest for Aabenraa, kom en Mand til at indtage Lederposten, der udelukkende helligede sig Skolearbejdet og i dette fik sin Manddomsgerning. Det var utvivlsomt en stor Hjælp for ham i Gerningen, at han som Nordslesviger var blevet tvésproget med dansk Modersmaal og tysk Kultursprog. Som 10-aarig Dreng var han (1780) blevet 
sendt til Skole i Christiansfeld, hvor han efterhaanden efterfulgtes af otte yngre Søskende. Hans Forældre var velhavende Mollerfolk, der ved samme Tid flyttede fra Hellevad til Taarning Vandmølle et Par $\mathbf{k m}$ Øst for Christiansfeld. 1784 sendtes han som en af de forste nordslesvigske Elever Syd paa til videre Uddannelse paa Brødremenighedens Pædagogium og Seminarium i Niesky. Bled og sart var han i Sindet. Han led derfor den første Tid i det fremmede meget under Hjemvé efter "Forældre, Slægt og Fædreland", som han udtrykker sig i den "Levnedsbeskrivelse«, alle Brødremenighedens Medlemmer skulde nedskrive før deres Død. Men snart optog Studierne ham saa meget, at især de sidste tre Aar paa Seminariet blev en lykkelig Tid for ham, efter at han $\mathbf{1 7 9 0}$ havde gennemgaaet en religiøs Krise i Forbindelse med dogmatiske Anfægelser under Forskningen efter Sandheden. Da Studierne var lykkeligt tilendebragt, fik han i Sommeren 1793 Lov til at rejse hjem paa Besøg. Han blev derefter ansat som Lærer ved Pædagogiet i Niesky, hvor han i Sommeren 1796 oplevede en underfuld Bevarelse under et Lynnedslag i Skolebygningen. Aaret efter drog han atter Nord paa, denne Gang for at overtage en Lærerplads ved sin egen Barndomsskole i Christiansfeld. Han skulde samtidig vare Præste-Medhjælper paa Stedet, baade i det tyske og det danske Sprog. Arbejdet synes at være lykkedes godt for ham, saa han 1801 kunde overtage Inspektør-Stillingen ved Skolen og samtidig indtræde i Menighedens Fldste-Raad paa Stedet.

Kun tre korte Aar forblev han dog i første Omgang i dette Embede, idet Unitetsledelsen 1804 kaldte ham som Protokolfører, for derved at lære én af sine yngre Medarbejdere nærmere at kende og give ham Lejlighed til at faa et fyldigere Indblik $i$ hele Unitetets vidtforgrenede Arbejde Verden over. Samtidig fik han Tilladelse til at indgaa Egteskab med Anna Sophia Kiørboe; hun var Købmandsdatter fra Christiania, født den 21. Juli 1779, havde været Elev paa Skolen i Christiansfeld og var nu Medlem af Søstre-Koret. Vielsen fandt Sted i Christiansfelds Kirkesal den 26. Oktober 1804, hvorefter de drog til Berthelsdorf 
i Sachsen, det daværende Sæde for Unitetsdirektionen, hvor Sønnichsen altsaa skulde være Sekretær en vis Tid i MissionsDepartementet.

Det blev en smertelig Afsked for die to Nordboer; og det blev nogle Aar med smertelige Oplevelser i det fremmede. Hustruen kom Døden nær ved en Dødfødsel (1805). Siden fødte hun Tvillinger (1807), af hvilke den ene straks derde og den anden, Emilie, forblev deres eneste Barn, siden gift med Forstander Friedrich i Gnadenfeld. Men Arbejdet i Missions-Afdelingen var til Gengæld baade oplivende og belærende for Sønnichsen og førte ham ind i Brødremenighedens verdensomspændende Virksomhed, dens særlige "Husholdning i den protestantiske Kirke" Jorden rundt.

1808 blev han ordineret til Diakon i Brødremenigheden og sendtes saa 1810 paany til Christiansfeld som Leder af Kostskolerne dér, idet han skulde overtage baade Inspektør- og Husfaderembedet. Saare lykkelig var han sammen med sin Hustru over denne nye Beskikkelse i Hjemstavnen. "Dermed fik jeg" skriver han senere i Tilbageblikket over sit Liv, "betroet en Gerning, som helt svarede til mine Ønsker og Anlæg og som tillige forekom mig at være af den største aandelige Betydning. Jeg var nemlig en stor Ven af Ungdommen, og jeg betragtede Opdragelsesinstituterne som et Redskab, hvormed Brødremenigheden kan bidrage saare meget til Kristi Riges Udbredelse".

Skolerne, der under Sønnichsens 6-aarige Fraværelse havde. været lidt tilfældigt ledet, trængte paa daværende Tidspunkt til en ny, arbejdsivrig Lederhaand. Krigen og Fattigdommen tyngede paa Nordens Lande og afholdt Hjemmene fra at sende deres Børn til Christiansfeld. Sønnichsens eget Barndomshjem f. Eks. mistede hele sin Formue i Statsbankerottens Aar. Men han tog fat med ungt Mod. Og hans medfordte Fortrolighed med Landets Forhold og hans hjertelige Personlighed drog atter nye Elever til Herrnhuter-Byen. En Overgang kom han til at staa som den mest betroede Mand paa Stedet, idet der ogsaa udenfor Skolegerningen gennem ham blev knyttet Traade fra den dan- 
ske Kirke til Christiansfeld, nemlig i Bibel- og Missionssagen, der kom frem i disse Aar under Tilskyndelser fra England. B. F. Røn ne, Dansk Missions Selskabs Stifter, Grev F. A. v. Hol st ei n-Holsteinborg, Lederen af de vestsjællandske gudelige Forsamlinger, Profefssor i Teologien Jens Møller ved Københavns Universitet, Sekretæren i Dansk Bibelselskab, stod i Samarbejde og Brevveksling med Sønnichsen. Rønne besøgte paa sin Jyllandsrejse i Sommeren 1823 ogsaa Christiansfeld og sender Takkeskrivelse til Sønnichsen for det behagelige Ophold i Byen og Menigheden. Gennem Christiansfeld gaar Anmodningen fra en ung Mand, Chr. Christensen i Hee, om at blive optaget i Selskabets Tjeneste og udsendt som Missionær. Ogsaa Korrespondancen fra det slesvigske Bibelselskab i Byen Slesvig ved dets Sekretær Kontrolør H. W. H a n s e n gaar gennem Sønnichsen. De engelske Udsendinge til Skandinavien i Bibel- og Missionssagen, Dr. St e in k o f i 1812 og Ebenezer Henders on i 1816, henvendte sig under deres Gennemrejse-Ophold i Christiansfeld ligeledes til Sønnichsen, den tidligere Sekretær i Brødremenighedens Missions-Departement.

Men Skolearbejdet med alle dets store og smaa Bekymringer - som Rytmen i Til- og Fragangen af Elever, mere eller mindre heldige blandt disse, Lærer-Vanskeligheder og Forældre-Urimeligheder, økonomiske Sorger og Sygdomme paa Skolen, Sønnichsens eget alvorlige Sygdomstilfælde i 1826 (Underlivsbetændelse), alt tærede paa hans i Forvejen ikke alt for stærke Kræfter og bøjede ham til Tider langt ned. Han søgte da Lise for Sind og Tanker i Bønnens Samtale med Frelseren, enten i Lønkammeret eller paa ensomme Spadsereture i den frie Natur, hvis Skønheder han havde et aabent $\emptyset_{j e}$ for. "Med hellig Henrykkelse betragtede jeg de majestætisk herlige Værker fra Guds egen Skaberhaand", siger han selv herom. Han havde tillige et følsomt Sind for Venskab, nærede overhovedet paa Forhaand Tillid til Medmennesker, men maatte til Gengæld lide dobbelt, naar Tilliden og Venskabet kom ud for Skuffelser. Ogsaa en enkelt større Rejse foretog han i sin Skoles og Menigheds Arin- 
de, nemlig til København (1819), ved hvilken Lejlighed han modtoges i Audiens af Kongen.

Mod Slutningen af Tyverne steg Elev-Tilgangen fra Norge, der efter 1814 en Aarrække havde været standset, igen betydeligt, vel ikke uden Forbindelse med den derværende Societetsforstander Niels Johannes $\mathrm{H}$ ol m s Virksomhed, som fik en Del Haugianere til at sende deres Born til Opdragelse i Christiansfeld. Men med Pariser Revolutionen 1830 og den Nationalisme, den vakte i Norge (gennem Henrik W er ge la n d) som andetsteds, svandt Tilgangen atter ind. I 1832 saa Sønnichsen sig derfor - i Betragtning af det ringe Elev-Tal og den herved voksende Gældsbyrde nødsaget til at bede om sin Afløsning. I 33 Aar havde han da ovet en Opdragelsesgerning ved Brødremenighedens Skoler. Som Forholdene var kommet til at ligge, blev der ingen større Fre til ham ved Afskeden; men alle maatte erkende hans Trofasthed i Anvendelsen af sine pædagogiske Talenter. For sin egen Part havde han gennem sine mangeartede Oplevelser i Skolearbejdet vundet wen dyb Viden om Livet og Menneskene«, der trods Malurten i Bægeret stemte hans Sind til Tak for Guds Godhed imod ham. Han forsøgte sig ogsaa med at give denne Hjertets Lovsang en poetisk Form, paa Tysk naturligvis.

Sønnichsen forlod med sin Hustru og Datter nu for stedse sin elskede Hjemstavn Nordslesvig. Vi forstaar, at det - efter hans eget Udsagn - skete "med meget blandede Følelser". Men Brødremenigheden var blevet hans andet Hjem paa Jord. Han undgik derved ogsaa personligt at maatte tage Stilling til de.n dansk-nationale Vækkelse, som i Trediverne og Fyrrerne brød frem i Grænselandet. I Berthelsdorf genoptog han sin Sekretærvirksomhed ved Unitets-Ledelsen. Men 1840 fik han et nervøst Febertilfælde, hvorefter han 1843 lod sig pensionere. Han flyttede nu til Datteren i Gnadenfeld, hvor han før sin Død (24. Januar 1852) endnu maatte lide under en Benskade efter et Fald (1846) og miste Synet paa det ene Øje efter et Slagtilfælde (1851). 
B. F. Rønne sagde om Sønnichsen, at han "med Iver for Guds Riges Udbredelse" forbandt "Kyndighed om Vejen og Midlerne til at naa Maalet«. En æedel Herrnhuter var han og den eneste Nordslesviger, der kom til at indtage en ledende Stilling i Christiansfeld, hvorfor hans Navn ogsaa bør huskes i Nordslesvigs Kirke- og Skolehistorie. ${ }^{4)} \ldots$

Somnichsens Efterfolger i Inspektor-Embedet blev den tyske Præst paa Stedet $P$ h i li p J a c o b R o en t g e n, der siden 1827 havde gjort Tjeneste i Menigheden. Han var fra Rhinlandet, født den 19. December 1777 i Brødrekolonien Neuwied ved Rhinen (skraat overfor Koblenz), hvor Faderen havde en meget betydelig Mabelfabrik. Han var bl. a. Leverandar til adskillige euro-. pæiske Hoffer mellem Paris og Petersborg, og fik i Anledning af den prøjsiske Konges Visit i Fabrikken Titel som dennes Agent ved Nedre-Rhinen.

Allerede som 4-aarig var Roentgen blevet sat i Brødremenighedens Kostskoler. Denne lidet barnlige Behandling har maaske bidraget til, at han stammede under Opvæksten, men har vel ogsaa styrket hans personlige Selvstændighed. Han gennemgik Pædagogiet og Seminariet i Niesky og blev 1798 ansat som Lærer ved Zinzendorf-Skolen i sin Hjemby Neuwied. Han vandt her sine Elevers fulde Hengivenhed, hvilket bl. a. kom til Udtryk i følgende vist ret usædvanlige Præstation. Med 5 af sine Elever tog han paa en Fodtur opad Rhinen til Svejtser Alperne, med det Resultat, at han bragte yderligere 14 nye Elever med tilbage til Skolen. Snart blev han ogsaa Viceinspektør.

1803 knyttedes han som Sekretær til Unitets-Ledelsen i Berthelsdorf. Men allerede Aaret efter sendtes han som Præst og Skoleleder til Gnadenfeld i Schlesien. Det viste sig snart, at han ogsaa her forstod at bringe "en frisk og munter Aand" ind i Institutet, idet han bl. a. genoptog sine Elev-Fodture i større Stil, nu op i de schlesiske Bjerge. Men fremfor alt blev han Talsmand for den national-preussiske Rejsning, der greb om

4a) Jfr. "Levnedsløb» i »Gemein Nachrichten« 1861, S. 750 ff. 
sig blandt den tyske studerende Ungdom, da Riget laa nedtrampet under Napoleons Jernhæl. Han fulgte "Turnvater" $J$ a h $\mathbf{n} \mathbf{s}$ Eksempel og indførte militære Øvelser i Undervisningsplanen, for derigennem legemligt og sjæleligt at hærde Eleverne. Og da saa Raabet om væbnet Modstand lød 1813 efter Napoleons Nederlag i Ruslands Vinter, meldte hele øverste Klasse paa Skolen sig frivilligt til Fanerne. Roentgen gav dem sin Velsignelse ved Afrejsen. En af dem faldt som Løjtnant i Slaget ved Leipzig. $\mathbf{O g}$ da Krigen var endt, var det kun naturligt, at Roentgen (den 18. Januar 1816) holdt en "uforglemmelig Takkegudstjeneste«, i hvilken ogsaa Fæstningen Kosels Belægning deltog. -

1818 blev Roentgen Præst i Neuwied. Hans Prædikener her karakteriseres som hjertelige og virkningsfulde. I kirkepolitisk Henseende var han Talsmand for Unionen mellem Konfessionerne. Broderkærligheden maatte staa over de individuelle Læreforskelle. Han knyttede saaledes ogsaa Venskabsbaand med en katolsk Præst i Neuwied, den senere kendte Konvertit og Missionsmand F. G os z n er i Berlin. Bibel- og Missionssagen, der jo ligeledes vandt frem paa tværs af de konfessionelle Skranker, havde hans fulde Tilslutning.

Fra denne rige Gerning ved Rhinen kaldtes Roentgen saa 1827 af Overledelsen til Præst i Christiansfeld i Grænselandet mod Nord. "Usigelig svært« blev det for den nu 50-aarige at foretage dette Embedsskifte, der forte ham til helt ukendte Egne og fremmedartede Forhold. Han regnede heller ikke med at skulle blive ret længe i den nye Plads og gav sig derfor ikke til at lære Dansk. Men da han ved Siden af Præstegerningen 1832 ogsaa fik betroet Ledelsen af Kostskolerne, hvor han i Forvejen havde Religionstimerne, blev han efterhaanden mere og mere bundet til Stedet og Landet. Med ungdommelig Energi tog han fat paa Opgaven og fik den fastkørte Vogn i Gang paany. 1835 foretog han med Held en længere Rejse til Sverige og Norge for at hverve nye Elever. Et Brev fra hans Haand til den i sin Tid kendte, fra Frankrig indvandrede Handskefabrikant Mattat i Randers, giver et Begreb om hans Fremgangsmaade. Det er da- 
teret Christiansfeld, den 20. September 1832, altsaa lige efter hans Overtagelse af Inspektør-Embedet, og lyder:

"Herrn C. Mattat in Randers. Ew. Wohlgeboren, habe die Ehre in der Anlage Ihren Wunsch zufolge, einen Plan über die meiner Direction anvertrauten Erziehungs Anstalten zu übersenden, wobey ich nur noch die Bemerkung hinzufüge, dass, da ich den Religions Unterricht bey unsern lieben Zöglingen selbst besorge - wöchentlich in 2 Stunden -, ich auch, wenn es von den Eltern gewünscht wird, die Confirmation derselben gratis übernehme; welches ich um so mehr mit wahrem Vergnügen thue, wenn, wie ich schon so oft mit Freuden bemerkt habe, die mit dem Gedächtniss gefassten Wahrheiten des Evangeliums sich auch in ihrer beseligenden Kraft an den Herzen unserer lieben Jugend beweisen.

Wenn Sie mir das Vertrauen beweisen, uns ein Kind anzuvertrauen, so darf ich hoffen, dass seine Erziehung under dem Gnadenbeistand Jesu Christi, zu Ihrer wahren Freude und Zufriedenheit nach Kopff und Herz gedeihen wird. In dieser angenehmen Hoffnung habe die Ehre mit der grössten Hochachtung mich zu zeichnen

Ew. Wohlgeb. ganz ergebener Diener

Ph. Roentgen, Prediger.

Skolen blomstrede paany. 1839 indrettedes en tredje Drengestue; 1845 var der 90 Elever, inclusive Dag-Eleverne; og Skolen var gæIdfri. Den evnerige og erfarne Skolemands Gerning var blevet kronet med Held.

Begivenheder i Familielivet knyttede ham yderligere til sit nye nordslesvigske Virkested. 1841 døde hans første Hustru og begravedes paa Christiansfelds "Guds Ager«. Datteren Emilie var 1840 blevet gift med Missionær $\mathrm{H}$ a u s e $\mathrm{r}$ i Dansk Vestindien. Sønnen L o u is, der havde studeret Medicin i Kiel, gik 1843 som Missionslæge til Syd Afrika. 1846 viede han to af sine Børn til Slesvigere, Sønnen A u g u t til Ida Mat thi esen og Datteren Louise til Christian Christiansen, hvorefter de nygifte Par flyttede henholdsvis til Göteborg og Petersborg, hvor Roentgen Aaret efter besagte dem.

Grænselandets nationalpolitiske Begivenheder maatte efter hans tidligere Erfaringer i Grænseegnen mod Øst naturligt nok stærkt optage hans Sind. Det var givet, at han maatte dele det tyske Standpunkt. Men da den slesvig-holstenske Rejsning i 1848-50 mislykkedes, saa' ogsaa han - sammen med mange an- 
dre tyske Embedsmænd - sig nødsaget til at forlade Landet. 1851 fik han Ansættelse som Societets-Arbejder i Königsberg, hvor han døde den 16. April 1855. ${ }^{\circ}$ ).

Den norske Forfatterinde C a milla Collet, Henrik Wergelands Søster, der var Elev paa Skolen i Christiansfeld 182729, giver i sin selvbiografiske Bog "I de lange Nætter" folgende. smukke Karakteristik af Roentgen som Religionslærer:

»Religionstimerne hos Roentgen regner jeg for de herligste, interessanteste Læretimer, jeg har oplevet i mit Liv. Vi glædede os alle til dem. Enhver af os var stolt ved bagefter at kunne sige: han spurgte mig i det eller det. Roentgen var blevet vor Helt; bare han gik forbi Anstalten, var det en Begivenhed. O, nej! han var ikke ung eller personlig indtagende! Det var en ældre, lidt tør og alvorlig. Mand uden for Timerne; men $\mathbf{i}$ dem blev han forynget, han blev varm og veltalende. Det var, som han havde noget rigtig glædeligt at meddele os. Og vi, hvor modtagelige! Som Smaabørn, man har lovet at skulle se skønne Rariteter og Verdens syv Underværker, sad' vi begærlige, spændte paa, hvad herligt han vilde vise og forklare os. Og han rullede op et Stykke Himmel efter det andet for vore undrende Blikke; men vi havde den Følelse derved, at vi sad lunt og trygt paa (len grønne Jord. Ja, det var netop fra dette Standpunkt, vi forstod Himlen bedst. Han udlagde os Biblen omtrent indtil Josva Bog; alt. imellem fortalte han os interessante og rørende Træk fra Livet, hvori Gud ikke altid blev nævnt i Ord; men hvad, behøvedes det? Enhver, der besøger Strassburger Dom, ved, at Erwin von Steinbach har bygget den, hans Navn vil tone usynligt under Buerne; men man udtaler let ikke ved enhver Enkelthed, man peger paa. Og $\mathbf{H}$ a n, der skabte Erwin og Jordens prægtigste Dom gennem ham, og den store Dom, som hvælver sig over dem begge, behøver vi at tage denne Bygmesters Navn idelig i Munden? Kan man undgaa at tænke paa ham hundrede Gange om Dagen? Saa knyttede sig vor unge, nyvakte Bevidsthed om $\mathrm{Ham}$ sig til alt, hvad der kom os for og bevægede os. om Dagen; vi kunde ikke tage Fejl af, hvad der var af $\mathrm{H} \mathrm{a} \mathrm{m}$, lige saa lidt som man kan tage Fejl af Lys og Morke. Alt, hvad der var vakkert, hvad der voldte ren, angerløs Glæde - naar vi fordrog hverandre - og gjorde hverandre noget godt - Tanken paa Hjemmet Naturens, Kunstens Herlighed, der endnu laa som en dæmrende Anelse i vor Sjæl! Gennem begge vore Lærerinder, hvoraf den ene var god og blid, den anden alvorlig, streng ag blid - jeg holdt af dem begge - talte $\mathrm{H}$ a $\mathrm{n}$ dadlende og rasende til os. Han trængte sig til os i alt, at vi kunde fatte og elske Ham, vi stakkels umyndige, uartig-

46) Jfr. "Levnedisløb» i »Gemein Nachrichten« 1859, I. 
fødte, i Sanselivet bundne, efter Liv og Frihed sukkende Menneskebørn, ja, for at vi rigtig kunde fatte og elske ham, steg han lyslevende ned til os i Jesu Kristi Skikkelse. Saadan lærte den kære Præst i Christiansfeld os det. Har jeg misforstaaet ham i noget, da vil han tilgive mig i sin Grav.« -

Roentgens danske Medarbejder i Skolerne (1834-40 og 1846 -51) og senere Afløser som Inspektør i Aarene mellem de slesvigske Krige (1851-59+) var - undtagelsesvis - en Mand fra Kongeriget, Peter Nyborg Hesselberg, Præstesen fra København og teologisk Kandidat fra Universitetet. Han havde fundet ind i Brødresocietetet i Hovedstaden og betragtede derefter Brødremenigheden som sit aandelige Hjemsted. Hans Ansættelse i Christiansfeld har vel været tænkt som en vis Afbalancering af den ellers overvejende tyskfødte Arbejderstab. 1846 fik han ogsaa overdraget det danske Aftensangs-Præsteembede efter Niels Johannes Holms Død (1845). Under den dansk betonede, politiske Kurs i Hertugdømmerne efter Treaars-Krigen blev han - naturligt nok - Skolens Leder. Men han var ogsaa den sidste indfødte Inspektør. For Eftertiden var det indvandrede Mænd Syd fra, der stod i Spidsen for Skolen. Deres Saga skal ikke nærmere omtales her.

III.

\section{Dagligt Liv i Institutet.}

Eleverne, som skulde medbringe Sundhedsattest, optoges sædvanligt i Alderen mellem 6 og 10 Aar, og udskreves igen i Konfirmationsalderen. I Regelen maatte man forpligte sig til et Ophold paa mindst tre Aar i Skolen. Fra omkring 1815 foregik ogsaa Konfirmationen for det meste i Christiansfeld.

Pensionsprisen laa aarligt omkring $60 \mathrm{R}$. Schl. Holst. Cour. for Drenge og 50 for Piger, og skulde erlægges kvartalsvis forud. Et Indskrivningsgebyr paa $4 \mathrm{R}$. betaltes ved Indtrædelsen. For disse Penge erholdt man saa Opdragelse og Undervisning, Kost og Logi med Lys og Varme og Vask. Krops- og Sengeudstyr maatte medbringes. Udgifter til Skolebøger og andre Rekvisiter, 
Johann Amos Comenius (Komensky), 1592 - 1670. Brødrepædagogikkens Grundlægger.
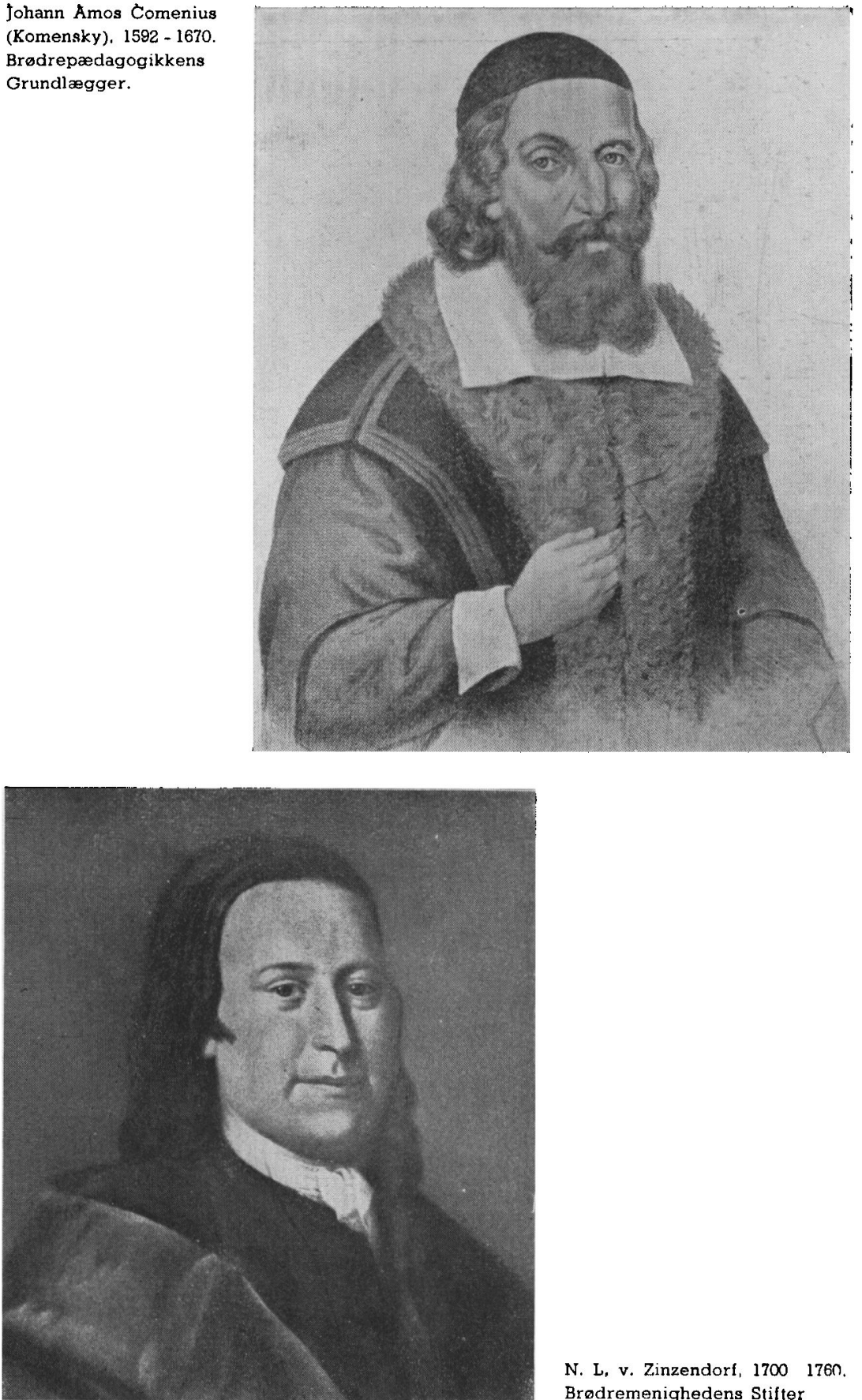

N. L, v, Zinzendorf, 17001760 . Brodremenighedens Stifter 


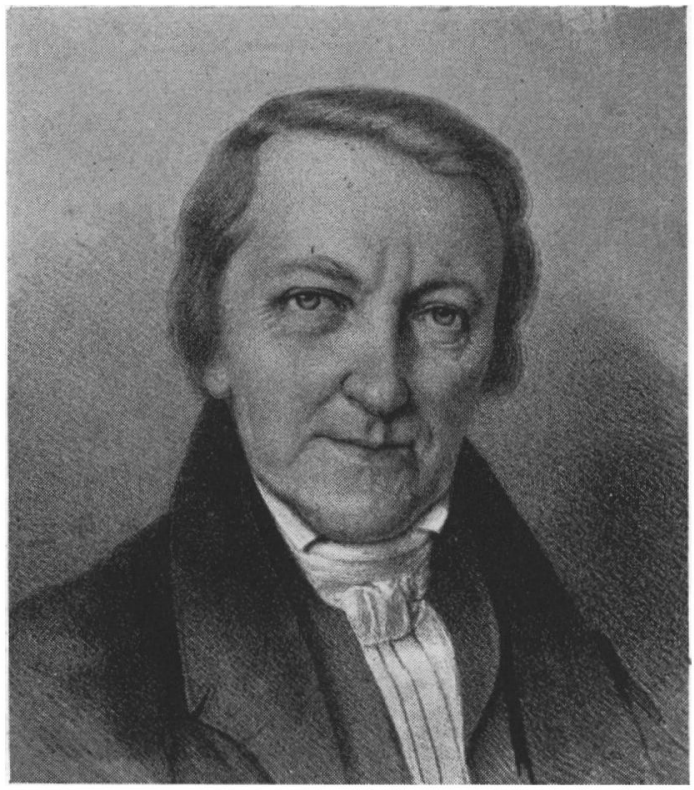

Philip Jacob Roentgen, 1777-1855

Skoleinspektor i Christiansfeld 18321850.

(efter F. C. Høy: Christiansleld 1773-1923)

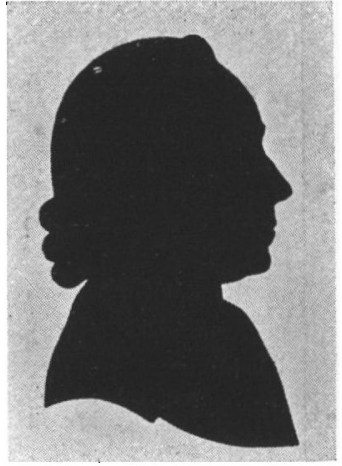

Jonathan Briant, 1726-1816. Christiansfeld-Skolernes Grundleggger

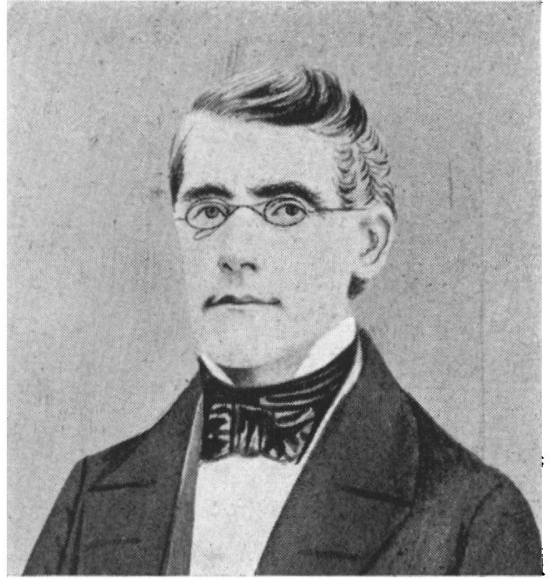

Peter Nyborg Hesselbjerg, 1804-1859. Skoleinspektor i Christiansleld 1851-1859. 
Privatundervisning, Reparation af Tøjet, Læge og Medicin, Ekstraforplejning, Lommepenge m. v. skreves paa Regning.

Undervisningsmateriellet i Skolen har efter Nutidsbegreber naturligvis ikke været rigeligt. Men det vigtigste i saa Henseende var og er jo ogsaa Lærerens faglige og pædagogiske Dygtighed, dvs. det levende Ords Undervisning, hvilken netop Herrnhuterne gik i Spidsen for. Som Fibel brugte man indtil 1791 en fra de tyske Brodremenigheder, der saa afløstes af den, som Skolens daværende Førstelærer David Schiffert udgav. 1799 fik hvert Barn en trykt Regnebog (Heynaz).

Særligt dygtige og egnede Elever blev af Styrelsen foreslaaet til at fortsætte Skolegangen paa Brødremenighedens højere Skoler i Tyskland (Pædagogium og Seminarium), hvorefter de saa overgik i Menighedens aktive Tjeneste.

Paa Timeplanen fandtes de almindelige Skolefag som Læsning, Skrivning, Regning og Mathematik, Religion (luthersk), Verdenshistorie, Geografi og Naturvidenskab, dertil Sprog, i forste Linie Tysk, men efter Ønske ogsaa Engelsk, Fransk, Latin, Dansk og Svensk, endvidere Tegning, Sang, Gymnastik og Haandarbejde, - altsaa et Realskolepensum. Undervisningsplanen blev iøvrigt delvis tilpasset efter den enkelte Elevs Anlæg og Ønsker. En aarlig Eksamen indførtes i 1790-erne. Fra Midten af det 19. Aarhundrede gaves en 14 Dages Sommerferie.

En streng Orden og Punktlighed herskede i Institutet. Hertil krævedes, at Eleverne var under stadigt Opsyn, baade under deres Arbejde og i deres Fritid. Man boede sammen paa Fællesstuer, 10 til 12 Elever paa hver med to Brødre som Stueforesatte, hvorved man tilsigtede at danne et "Livsfællesskab», en "Familie«. Adspredelse sørgedes der for gennem fælles Spadsereture, med Skøjteløb om Vinteren og Badning om Sommeren, og saa anden. Underholdning indendørs, f. Eks. ved Oplæsning og Indøvelse af dramatiske Værker eller ved smaa Koncerter. Ogsaa den regelmæssige fælles Kirkegang Helligdag og Søgnsdag gav en tiltrængt og inspirerende Afveksling i Dagens Program. I 1840erne saa dette f. Eks. saaledes ud: Kl. 5: Vækning 
(om Vinteren noget senere), Morgensang og -mad, 6-7: Lektielæsning, 7-12: Undervisning med Frikvarter og Frokost, 12: Middag og Fritid, 2-4: Undervisning, Mellemmad, 4-7: Arbejdstid, 7: Aftensmad og Fritid: 9: i Seng.

Maaltiderne indtoges i Fællesskab i Spisesalen. Forplejningen leveredes fra Korhusenes Køkkener. Først 1841 fik man efter et længere næret Ønske eget Køkken. Kosten synes at have været jævn, men til Gengæld nærende, selvom der naturligvis jævnligt blev klaget over dens Utilstrækkelighed fra Elever, der var forvænnede hjemmefra. En Overgang imødekom man uheldigvis - Klagen ved at indrette et Ekstrabord mod særlig Betaling. - Man sov i fælles Sovesal. For syge Elever var der indrettet en mindre Sygestue.

Besøg af Forældre og Bekendte paa Stedet saas ikke gerne, idet disse i Regelen gav Anledning til mulige Ophævelser fra Elevens Side, og i det hele til Forstyrrelser i Opdragelsens Gang. En Foresat skulde derfor altid overvære Samværet mellem de besøgende og Barnet. Besøg hjemme var - delvis paa Grund af Afstandene og Rejsens Besværligheder, men ligeledes af pædagogiske Grunde - yderst sjældne. Skulde Maalet med Skolen naas, maatte Eleven i den fastsatte Tid helt indordne sig paa Stedet og betragte dette som sit midlertidige Hjem. Elevens Korrespondance med Forældrene gik af den Grund altid gennem Institutfaderens Haand.

Til Gengæld sogte Skolen saa i fuldeste Maal at byde Eleven et virkeligt Hjem paa Stedet. Et godt Indblik i denne Bestræbelse faar vi gennem en Pro Memoria, som Jonathan B riant ved sin Visitats i 1790 affattede. Det skal gengives: Oversættelse:

"Af Institutfaderen, som forestaar de to Pensionsanstalter for Drenge og Piger i Christiansfeld, ventes det:

1) At han bærer Opdragelsen af den ham betroede Ungdom for Frelseren paa sit Hjerte og helt lever for denne sin Opgave;

2) At han er opmærksom paa Børnenes aandelige Udvikling ("Herzens Gang() og i det Øjemed staar i fortrolig 'Tankeudveksling med Kor-Plejerne, og lader det være sin Hovedopgave at faa Børnene til 
at holde af Frelseren, saa de gaar frem i Kærligheden til og Erkendelsen af Ham, og blive bevarede for alt, som besmitter;

3) At han sarger for Dannelsen af de unges Sind og Tanke, saa at et klart, oprigtigt, ædelt, uaffekteret Væsen ved Guds Naade maa indpodes $i$ deres Hjerter, og det mørke, duigte, indeklemte, trodsige, saa vel som det frække, raisonerende, satiriske maa holdes nede;

4) At der vaages over Flid og Troskab i Skolegangen, at Lektierne læses regelmæssigt og ordentligt, hvilket alt til Stadighed droftes sammen med Skoleinspektøren;

5) At Velopdragethed og gode Sæder fremmes, og de Unge stadig tilskyndes hertil;

6) At der nøje agtes paa Børnenes Sundhed og alt undgaas, som kunde skade denne, overhovedet at der $\mathbf{i}$ det Stykke udvises den Troskab og det Tilsyn overfor sunde og syge, som Forældre vilde udøve;

7) At der holdes paa Renlighed og Orden, saa vel hos hvert Barn særskilt, som paa Stuerne og i Klasserne;

8) At de Børnene tilhørende Ting som Klæder, Vasketøj og Værdigenstande holdes i Orden og god Stand, som overhovedet den ydre Omsorg for Institutbornene paahviler Husfaderen og -moderen;

9) At der ogsaa vaages over Stue-Brødrenes og -Søstrenes hele Opførsel, deres Behandling og Vejledning af Børnene, saavel som disses legemlige Pleje;

10) At der føres ordentligt Regnskab over Indtægter og Udgifter, korresponderes med Forældrene, og Institutplanen i det hele overholdes; overhovedet at Institutfaderen og hans Hustru staar i stadig Forbindelse med Institutdirektionen paa Stedet, intet af Vigtighed foretager sig uden at raadøre sig med denne, fra Tid til anden for denne fremlægger Institutets økonomiske Status, og i stort som smaat anser sig som ansvarlig overfor denne.« - - -

I en "Kort Efterretning om Opdragelses-Instituterne for Drenge og Pigebørn i Christiansfeld i Hertugdømmet Slesvig«, trykt 1846 i Odense, siges der bl. a., at Opdragelsen dersteds har "en dobbelt Bestemmelse, dels den at danne Mennesket for det jordiske Liv, dels og fornemmelig den, at danne det til Borger Jor hin salige Evighed (smlgn. Mark. 10,14)«. Maalet søges naaet 1) ved Evangeliets Prædiken, 2) ved Aandens Dannelse, 3) ved det udvortes Menneskes Opdragelse.

Under det forste Punkt fremhæves den evangeliske og punktlige Aand, som Opdragelsen ledes i. Opdrageme vil være Elevernes Venner og ved deres Eksempel vise, "at man kan være en Christen og dog glad og munter«. Behøves der Tilrettevis- 
ning, maa det - med Kristus som Forbillede - være Kærlig. heden og ikke Vreden, som dikterer denne. Legemlig Tugtelse undgaas helt, alt for megen Moraliseren ligesaa, idet denne sidste er en "Nedværdigelse af det guddommelige Ord" og "sløver den ungdommelige Følelse for vor hellige Tro".

Under Punkt 2 betones det praktiske og karakterdannende i Undervisningen. Man vil "undgaa al død, abstrakt Lærdom" og gøre Undervisningen livsnær. I Sprogundervisningen lægges derfor Modersmaalet til Grund. I Verdenshistorien er det Dømmekraften, som skal skærpes, og ikke blot Hukommelsen, som skal øves. (Altsaa intet Terperi!) I Naturhistorien ses paa Udvikling af Iagttagelsesevnen og af Selvvirksomheden. Tegning og Sang betragtes som pædagogisk grundlæggende Fag. Om det sidste siges: "Vi ansee Musik som en vigtig Deel af Opdragelsen, idet Intet er saa meget skikket til paa rette Maade at forædle og opløfte Gemyttet som netop denne. Fortrinligvis erkjende vi dette med Hensyn til Sangen, hvor tillige Vanen til fælles Samvirken bidrager til at vække Almenfølelse.« -

Punkt 3 understreger Gymnastikkens Betydning og i det hele taget Legemets Pleje og Hærdning gennem Afvaskning, Badning, Leg, Fodture, Havearbejde o. lign. -

En Forstanderinde i Pigeskolen har med sirlig Skrift optegnet sine Tanker om den herrnhutiske Opdragelse $i$ et Hæfte, hvori vi blandt meget andet smukt og rigtigt kan læse følgende (gengivet i Oversættelse):

Om Eleverne siges der: "Et Barn skal anses som en Guds Engel, bestemt til Tjeneste for Ham her paa Jorden, og dertil sendt af Ham med en for Tiden endnu forseglet Bestemmelse. Og Opdragelsens Maal er det nu at løse dette Segl." -

Om Opdragerne hedder det: "Naar Opdragergerningen er af guddommelig Art og Børnene skal dannes til Guds Tjenere, da maa deres Opdragere frem for alt andet være begavede med Guds Aand .... Kærlighedens Aand .... Denne Aand maa besjæle de Foresatte og fra dem forplante sig til Børnene .... 
Opdrageren skal have Erbødighed overfor Barnets tilkommende Bestemmelse. Han maa i de Smaa kunne ane den fuldt udviklede Plante.» -

Om det religiøse Moment i Opdragelsen forklares: Barnet maa lære at føle Trang til en Frelser og erkende sit eget Menneskelivs og hele Menneskehedens religiase Maal. Dette opnaas imidlertid ikke ved "Prækeri« - "overhovedet vogte man sig for alt overdrevent, unaturligt, affekteret, hvilket ingen Steder skader mere end i Religionsspørgsmaalet! — , men ved at "en religiøs Aand omgiver dem .... I selve Menighedens Tilværelse har man den skønneste Understøttelse for vore Børns religiøse Opdragelse." -

Om Undervisningens Kunst hedder det, under Henvisning til Pestalozzi, hvis Kristendomsfjernhed dog beklages: „Vækkelsen af Barnets Interesse er al Pædagogiks egentlige Maal .... efter Grundsætningen: Hvad der kommer fra Hjertet, gaar ogsaa til Hjertet .... Hav selv Interesse for det, du lærer, saa vil du ogsaa vække Interessen hos dine Elever!«

Sammenfattende siges der: "Vi strør Sæden i modtagelige Hjerter, men ved ikke, hvornaar den vil spire og bære sin Frugt ... Om nogensteds, gælder det i Opdragelsen: at tro uden at skue. Tro vil vi paa Sandhedens Kraft, som vi lærer vore Børn, tro paa Modtageligheden hos dem, tro paa Herrens Naade, som vil finde enhver i Tidens Fylde. Og ingen anden Løn vil vi søge end den: redeligt at have fuldbragt vort Værk. Ordet hos Apostlen Jakob skal være vort Løsen: Derfor, værer taalmodige, Brødre! indtil Herrens Tilkommelse. Se, Bonden venter paa Jordens dyrebare Frugt og bier taalmodigt efter den, indtil den faar tidlig Regn og sildig Regn. Værer ogsaa I taalmodige, styrker eders Hjerter; thi Herrens Tilkommelse er nær.« (5, 7-8). -

Skønnere og sandere kan Opdragelsens Maal vel næppe beskrives. At Idealet saa ikke altid blev naaet, er en anden Sag. Der er svigtende Evner og braadne Kar i alle Lejre. Men Viljen til at naa det fuldkomne opflammedes stadig paany. 
Vi ser Herrnhuterne gaa ind for den nyere Tids frie Skoletanker, medens de samtidig bevarer det væsentlige i de gamle, fremfor alt det religiøse Grundlag for Opdragelsen og Undervisningen.

IV.

\section{Herrnhutisk Skolesyn.}

Det er allerede blevet berort, at Christiansfeld-Skolernes kristne Karakter tilskyndede en Del Forældre til at betro deres Børn til Herrnhuternes Opdragelse. Denne Bevæggrund gjaldt især for de vakte Hjem i de gudelige Forsamlinger ved Slutningen af den 18. og Begyndelsen af det 19. Aarhundrede. Disse Lægfolkets religiøse Sammenslutninger var fremstaaede som en Protest fra gammeldags Kristne mod Tidens nye Fornuftkristendom, der udbredtes af Landets rationalistiske Præsteskab. I Brødremenighedens læge Kirkesamfund saa man derimod Bibelens Tro og Sæder bevarede, og onskede derfor paa dette Sted at skærme deres unge mod "den forføriske Verden" under Opvæksten. Gang paa Gang fremhæves det $\mathbf{i}$ disse vakte Forældres Breve til Christiansfeld, at Hensigten med at sende Børnene ene og alene er Hensynet til deres kristne Bevarelse. Der kan f. Eks. henvises til Købmand H. C. B randt i Svendborg, et fremtrædende Medlem af de gudelige Forsamlinger paa Fyn, der sendte sine fire Born til Christiansfeld og herom ytrer følgende: "Aarsagen til vore Børns Aflevering i Christiansfeld er ene og alene den, at de maatte blive bevarede for den onde Verden, og at de maatte blive og forblive Guds Børn i Tid og Evighed."

En norsk og en svensk Røst skal ogsaa meddeles. Provst J. Hørby e i Krogstad skriver i Anledning af sin anden Søns Optagelse i Christiansfeld Skole: "Vi lægger ham derfor først paa Frelserens forbarmende Hierte, og vil blive ved at bede, at han vil selv i Naade tænke paa ham og drage hans unge Hierte hen til sig; og demæst overleverer vi ham og til Dem kiereste Broder, og beder De vil i alle Henseende være ham i vort Sted, hvorom vi og er fuldkommen forsikrede." - 
Bjergværksejer J. W. v. D a $1 \mathrm{~m}$ a n, Roo ved Liedköping, skriver med Henblik paa sine to Sønners Ophold i Christiansfeld-Institutet: "Emedlertid är min högsta glädje att de äro på ett så gått stelle, hvorast deras hjertan måste insuga kärlek ock vördnad för Frelsaren, som kan gifva dem nåd ock kraft att blifva bevarade ifrån verldens förföriska...... lefnad “. -

Men nu møder vi tillige det mærkelige, at ogsaa en Del af disse vakte Lægfolks og gammeldags Præsters bitreste Modstandere i Tiden, de rationalistiske Præster, der modarbejdede Forsamlingsfolkene som overtroiske Sværmere og overdrevne Hellige og selv holdt paa en "fornuftig" og "naturlig" Opdragelse, sendte deres Børn til det samme Christiansfeld. F. Eks. de to kendte Præster i København, Stiffsprovst Dr. F. P l u m ved Frue Kirke (siden Biskop paa Fyn) og Provst F. C. G u t f el d ved Holmens, og endvidere den bekendte Provst N. Wergel a n d paa Eidsvold i Norge. Og disse fremskridtsvenlige Gejstlige ytrer ogsaa deres Tilfredshed med Opdragelsen i Christiansfeld. Som Provst Wergeland skriver: "Med Glæde anbetroer jeg dette mit kjære Barn i Deres Hænder, og takker Forsynet, som endnu i Slutningen af hendes Barndom har aabnet hende saa skjøn en Lejlighed til sædelig og intellectuel Dannelse i en med Rette saa berømt Stiftelse». -

At herrnhutisksindede Præster - som f. Eks. J. E w ald i Hviding, A. G. F abricius i Humptrup, M. Hoyer i Nebel, K a a l u n d i Hemmet, J. R ei er sen i Nibe, O. P r a ëm i Øsløs, R. B a I s levi Haarslev, Mygind i Dreslette, P. Saxtorph og S. S ch i ød te i København, J. Hørbye i Krogstad, O. J. A n d r é n i Göteborg, H. H. V e n $t$ i Hademarschen - ønskede at anbringe deres Børn i Christiansfeld, var kun naturligt og venteligt. Men hvad tiltrækkende kunde de »oplyste« Præster finde paa samme Sted? At ogsaa de bragte deres Børn til Brødre-Byen, tyder paa en særlig Egenskab ved denne Skoles Aand og Indretning. Hvad var det da, der virkede saa dragende?

For en Del Grosserere og Fabrikanter, Officerer og Embedsmænd, adelige Godsejere og Proprietærer, Præster og Læger var 
det maaske nok Lejligheden til at lære det tyske Sprog, der vejede med i Overvejelserne angaaende Anbringelse af deres Børn. Men for de fleste Forældre synes det dog gennemgaaende at have været noget dybere, som lod dem vælge HerrnhuterByen til deres Børns Skolested. Det kan ikke have været noget Mode- eller Partisynspunkt i Øjeblikket; da vilde Skolen være gaaet ind sammen med Døgnets Stromninger. Den fortsatte Tilslutning opnaaedes heller ikke ved Nivellering af de forskellige pædagogiske Standpunkter, men snarere ved en $U d d y-$ belse af Grundlaget for Skolens Livog Arb e j d e.

Vi kommer da til det Resultat, at vi bør søge denne Skoles bærende Grundlag $i$ selve den herrnhutiske Kristendoms-og Menighedsforstaaelse, der paa tværs af de stridende Opfattelser sogte tilbage til det oprindelige apostoliske Udtryk for Kristendom og Kirke, ikke uden Lidelse og Forfølgelse. I al Korthed kan det herrnhutiske Kristendomssyn betegnes som en Genopdagelse af den levende Kristus, ikke som Læresystemets, men som Fællesskabets store $S k a b e r$, og dette igen ikke som en fjern Fortidshelt eller en engang kommende Himmelfyrste, men som den $n æ r v æ r e n d e H e r r e$ og Hyrde i s in Menighed pa a J ord, der skaber Tryghed og Glæde i Menneskers Sind, disse Hjemmets to største Goder. Denne Brødremenighedens evangeliske Aand var det, som bestemte Tonen og Metoden i Christiansfelds Opdragelsesinstitut. Og denne nytestamentlige Grundvold var den dybeste Aarsag til, at Christiansfeld-Skolen formaaede at samle Elever fra baade Adelsslot og Smaakaarshjem, fra gammeldagstroende og nydagsindstillede Kredse. Jeg skal da nu forsøge i store Linier at give et Tværsnit af detherrnhutiske $\mathrm{S} k$ o l es y $n$, og benytter hertil 0 . Uttend örfers værdifulde Studie: Zinzendorf und die Jugend, Die Erziehungsgrundsätze Zinzendorfs und der Brüdergemeine, 1923.

Som Elev fra Pietismens førende Skole, F r a n c k es Adels- 
pædagogium i Halle, tænkte $Z$ in $z$ e $\mathrm{n}$ d or f oprindeligt paa at faa sin Livsgerning indenfor denne Skoles Kreds. Men da Omstændighederne 1722 havde ført til Herrnhuts Grundlæggelse paa hans Godsterritorium ved mæhriske Eksulanter, og han dermed havde overtaget Ansvaret for disse forjagede Haandværkeres timelige og evige Vel, gik han ogsaa straks i Gang med at indrette en Skole, til at begynde med efter Halles Mønster. Men snart voksede - svarende til hans nyerhvervede herrnhutiske Menighedssyn - ogsaa hans Skolesyn ud over de halleske Rammer. Og han skabte da i Forbindelse med den nye Menighedsdannelse ogsaa et selvstændigt herrnhutisk Skolevæsen. Det var i første Linie Pietismens moralistiske Omvendelsesmetodisme fra Halle, Zinzendorf søgte at overvinde gennem sin nye evangeliske Tro paa Naaden i den Korsfæstedes. udgydte Blod. Hans pædagogiske Grundsætninger fik hermed noget frit og frejdigt over sig i Modsætning til 'Tvangen og Askesen hos Pietisterne. Tillige gav hans pædagogiske Opdagelse af Barnet og dettes individuelle Livsindstilling ham en ny og afgørende Forstaaelse af Sammenhængen mellem Sjæl og Legeme og dermed ogsaa mellem den religiøs-etiske og den fysiskpsykiske Udvikling under et Menneskes Fremvækst. Paa dette Punkt skal Zinzendorfs Hovedindsats søges. Barnet skal under Opdragelsen behandles som et Barn og ikke før Tiden gøres til en voksen. Man skal erkende og respektere dets Individualitet. og dets gradvise Vækst frem moả personlig Selvstændighed. Naturen i Barnet skal ikke holdes nede eller endda dræbes, men helliges og dannes. Med disse Tanker brød Zinzendorf nyt. Land i Tiden. Han skabte en ny selvstændig Syntese mellem Franckes Pietisme og Rousseaus Naturalisme, idet. han imødekom begges berettigede Krav, Hensynet henholdsvis. til det kristelige og til det menneskelige. Og samtidig undgik han deres Afsporinger, det indestængte til den ene Side, og det overfladiske til den anden. Derved fremkom en sund og frugtbar Vekselvirkning mellem det kristne Budskab og det menneskelige Behov, mellem Himmel-Sæden og dens Jordbund i Bar- 
nehjertet. Paa dette væsentlige Punkt fortsatte han Linien fra selve det Nye Testamente, stærkest udtrykt i J e s u egen evangeliske Syns- og Handlemaade, og videre fra de store kristne Opdragere, deriblandt især Vesterlandenes maaske største Pædagog, Tjekkeren og Brødrebiskoppen Amos Comenius fra det foregaaende Aarhundrede. Og han beredte Vejen for det følgende Aarhundredes førende Folkeopdragere, blandt disse Pestalozzi i Svejts og Grundtvigog Kold herhjemme. ${ }^{5}$ ) Hvordan stillede Pædagogen Zinzendorf sig til de for Opdragelsen saa vigtige Spørgsmaal om Gudsbilledet i Mennesket og om Kirkens Arvesyndsdogme? Efter Uffendörfer kan der ikke være Tale om, at han teoretisk har forkastet det kirkelige

5) Der kan i denne Forbindelse være Grund til at standse lidt ved et enkelt Spørgsmaal, som spiller en afgørende Rolle i alle pædagogiske Overvejelser, nemlig Spørgsmaalet om det, Bibelen kalder G u d sbilledet i Mennesket, og i nøje Sammenhæng hermed Spørgsmaalet om det kirkelige Arvesyndsdogmes Indflydelse paa Opdragergerningen. Enhver pædagogisk Bestræbelse maa, hvis den ellers vil være konsekvent og tro mod sit Kald, bygge paa det godes Mulighed i Mennesket, det gudbilledlige i bibelsk Sprogbrug, som ogsaa efter Bibelens Lære - skal kunne fremelskes til større eller mindre Fuldkommenhed. Hvis derimod - som Kirken lærer det - den fra Adams, det saakaldte første Menneskes grundlæggende Fald nedarvede Synd har udslettet Gudsbilledet i Mennesket, saa dette mere ligner Guds Antipode, Djævelen, da maa al Opdragelse paa Forhaand synes at være forgæves. Kendsgerning er ogsaa, at Arvesyndsdogmet har været den stadige Klods om Benet paa Kirkens pædagogiske Tiltag ned gennem Tiderne, selv om det maa siges, at den mere har gjort sig gældende i Teorien end i Praksis. Man har da klaret sig igennem paa forskellig Vis, den katolske Kirke mere konsekvent med sit Dogme om den i Daaben indpodede Naade, dvs. den nyoprettede guddommelige Natur i Mennesket, medens den protestantiske Kirke har slaaet sig til Taals med halve og inkonsekvente Opfattelser. Den katolske Kirke har paa sit sakramentalt-dogmatiske Grundlag udfoldet en betydelig folkeopdragende Virksomhed, medens de førende protestantiske Opdragere ikke saa sjældent valgte deres Vej uden om den officielle Kirke og knyttede deres Tanker direkte til Jesu Lære om Mennesket, med Islæt fra den græske Filosofi. De banebrydende protestantiske Pædagoger har maaske ikke just aabent bek empet det kirkelige Arvesyndsdogme, men de har i alle Tilfælde ikke regnet med det $\mathrm{i}$ deres Idéer og Bestræbelser, men til Gengæld peget paa Kristendommens Stifter, der uden at hildes af foruidfattede Meninger selv aktivt gik ind i Opdragergerningen og fremstillede Barnet, slet og ret som det er fremgaaet af Guds Skaberhaand, som det store kristne Forbillede paa Tro og Livsførelse. -

Det kunde derfor hænde, at Tiden nu ogsaa var modnet til, at vi - ogsaa med god kirkelig Samvittighed - kan tillade os at se historisk paa den bibelske Beretning om Menneskets Skabelse og om dets 
Arvesyndsdogme. Men i Praksis arbejdede han ud fra den Forudsætning, at Mennesket er skabt i Guds Billede og derefter er faldet i Synd; og Synd er for ham dybest set ikke Umoralitet, men Vantro. Derfor gjaldt det om at vække Barnets Tro til Live igen, hvis det voksne Menneske havde sat den over Styr. Og det kunde kun den under Kristi Kors vakte Kærlighed udrette. Og denne praktiske Broderkærlighed var for ham grundlæggende og afgørende overfor alle pædagogiske Teorier. "Jeg er sikker paa", siger han engang, "at jeg med min enfoldige Kærlighed naar videre frem end alle andre, selv med deres mest udsøgte Maksimer." Denne enfoldige Kristus-Kærlighed var for

Synidefald. Vi forstaar da Bibelens første Blade ikke mere som en historisk Beretning om det formodede første Menneskes Skabelsie og Fald med samt dette sidstes negative Indflydelse paa alle senere Slægter paa Jord. Men vi opfatter Skabelses- og Syndefaldsberetningen som den af Kristendommen godtagne religiøse Myte om hvert eneste Menneske, der uldgaar "saare godt" af Guds gode, stadig lige aktive Skaberhaand, med Muligheden baade for Bevarelsen og Udfoldelsen af Gudsbilledet og tillige fior Faldet i Synd og Fortabelse. Ethvert Menneske paa Jord er - som al anden Skabning unider Himmelen - Gud lige nær fra Begyndelsen og har den samme Mulighed for at staa eller falde og at oprejses paany.

D a a b e n i Kirkens Praksis bliver ud fra dette Synspunkt egentlig først det, den efter Jesu Opfiattelse skulde være, nemlig "en Velsignelse«, dvs. en hellig Handling, der kultisk-billed.ligt fremstiller Guds Skabelse af Mennesket i sit Billede, og ikke - som i den katolske Dogmatik - en magisk Fjernelse af Arvesynden eller - som i den protestantiske - en kultisk Skik, der har mistet sin indre $\mathrm{Me}$ ning og Berettigelse. Hvorfor aandelig Renselse af et Barn, der dog ikke selv har syndet, maa den tænksomme uvilkaarligt spørge! Nej, Daabshandlingen i Menighedens Midte er i kultisk Skikkelse Bibelens første Kapitel gentaget for vore undrende Øjne. Vandets primære Egenskab er jo ogsaa dien skaibende - og ikke den rensende. Daaben vil paa den Maade blive fyldt med nyt og levende Indhold. Den bliver det kultiske Sindbillede paa Guds suveræne, fortsatte Skaberakt, og samtidig bliver den det virkeligt bærende Grundlag, hvorpaa Opdragelsen baade er mægtig og pligtig til at bygge sin livsnødvendige Gerning. Det gælder i denne nu Kampen og Omsorgen for at bevare Gudsbilledet mod Udslettelse i det enkelte Menneske og at give det de bedste Vækstbetingelser, at det kan vinde mere og mere tydelig Skikkelse i Mennesket og blive til det, vi kalder Karakter, Gudsbilledet fast og varigt præget i Menneskehjertets levende Kødtavle. Først para denne gode Grund. som Skaberen selv har lagt - som det kultisk fremstilles i Daabshandlingen - faar Opdragelsen sin fulde og igangsættende Berettigelse. Saadan maa vi ogsaa forstaa Slutningsverset i Grundtvigs kendte Skolesang: Saa tal nu sandt om smaat og stort og iævnt om alt det høje, thi godt er alt, hvad Gud har gjort og klart er Barnets Øje! 
ham Drivfjederen i Opdragergerningen. Ikke blot i Menighedssalen under Gudstjenesten, men ogsaa i Skolestuen under Undervisningen lød det stadig til ham fra den Tornekronede: "Dette har jeg gjort for dig! Hvad gør du for mig?" Kærligheden alene skaber Liv og Vækst, ogsaa i Opdragelsen.

Den M e tod e, Zinzendiorf derfor vilde se anvendt i Brodremenighedens Undervisning og Opdragelse, var $\mathrm{K} æ \mathrm{rli} \mathrm{ghe}$ dens og Frihedens, og ikke Dressurens og Tvangens. Som et ydre Kendetegn herpaa var det f. Eks. forbudt at bruge korporlige Straffe i Brødremenighedens Skoler. Aandens og Kærlighedens indre Myndighed skulde være den afgørende. "Vi vil ikke paabyde eller forbyde vore Børn noget«, siger Zinzendorf, "men søge at vække en inderlig Kærlighed til Frelseren i deres Hjerter. Saa er de paa den rette Vej, og alt det øvrige bliver da et Spørgsmaal om god eller daarlig Opførsel ...... Kommandere dem kan og vil vi ikke. Vi skal ikke herske over deres Samvittigheder, men derimod stadig bedyre og bevidne for dem, hvor godt vi befinder os i Frelserens Samfund.« - "Man skal ikke paatvinge Børnene sine egne Ønsker", siger han en anden Gang, wmen utrætteligt føre dem lutter himmelske Ting for Øjnene, indtil man opdager, at Naaden og Sandheden har fæstet Rod i deres Sind.... Det er deres egne guddommelige Anlæg og Bestemmelser, de skal vokse og formes efter, og det ikke med nogen Slags Pres eller Vold, men under Indflydelse fra ens eget gode Eksempel.« -

Opdragelsens $\mathrm{T}$ e m p o skal derfor ikke paa nogen Maade forceres, men følge Barnets egen naturligeVækst o g Udvikling. Zinzendorf vender sig med dette Synspunkt kraftigt bort fra den pietistiske Metode, der krævede og konstant drev paa Elevens brudagtige Omvendelse. For ham gjaldt det om ikke at foregribe eller forstyrre, men at begunstige og fremme Væksten mod selvstændigt personligt Tros- og Tankeliv. Børnene er for ham Poder i Guds Urtegaard, hvis ydre og indre Vækst helst skal følges ad. Om sine egne Børns Opdragelse siger han i Tilslutning hertil: wMine egne Børn har jeg 
ladet leve og vokse, som de selv maatte, har ikke forbudt dem noget ud over det, som var til Skade for Menigheden. De har i min Nærværelse kunnet opføre sig, efter som de var skabte, og jeg er blevet deres fortrolige .... Gør man det anderledes, bliver det tilsidst uudholdeligt. Det gaar til en Tid. Saa kommer de ind $\mathrm{i}$ Lømmelalderen og falder deres Omgivelser til Besvær, indtil de faar Greb paa at skjule deres Ondskab og dermed bliver til Hyklere. Hvilken Jammer og Elendighed er vi saa ikke kommet ind i! Saa snart nemlig Børnene begynder at skjule deres Tanker, er de ikke mere Born. Det er netop det vanskelige ved Børneopdragelsen at faa forhindret, at deres Tanker og deres Ord gaar hver deres Veje .... Det bedste, man kan gøre, er at søge at blive Børnenes bedste Ven og fortrolige og saa iøvrigt at lede dem ind under Helligaandens Indflydelse. Der findes i Bibelen ikke noget om, at Forældre skal tvinge deres Børn til at blive Guds Børn, men Børnene skal selv komme til at tænke og bekende overfor Frelseren: Min Fars og Mors Tro gør, at du uopholdeligt drager mit Hjerte! - Naar derfor Forældre, som først selv helt har overgivet sig til Frelseren, kan vinde deres Børns Hjerter, da har de ogsaa vundet Sejren i Opdragelsen.«

Som Medaljens Revers, der naturligvis ogsaa findes, peger Zinzendorf paa, at frit og mildt opdragne Børn ikke altid bliver de artigste, og endvidere, at de største Mennesker undertiden har gennemgaaet den strengeste Opdragelse. Men her overfor maa man saa igen huske paa, at de alt for artige Børn sjældent bliver til noget særligt, og at mange bliver adelagte $i$ den haarde og tvungne Opdragelse.

Det er indlysende, at den herrnhutiske frie og aandsbestemte Opdragelsesmetode stiller de største Krav til o p dra geren. Han skal virke og vinde alene ved sit Eksempels indre Myndighed og Vidnesbyrd. $O g$ som det er paa denne Linje, at Slagene vindes - og tabes i Hjemmene, saaledes ogsaa i Skolerne. Zinzendorf understreger i denne Forbindelse stærkt, at Skolens Aand skal være en $\mathrm{Hj}$ em mets Aand; 
alle de, der har med Børnene at gøre, Lærerne saa vel som Husfædrene i Kostskolerne, skal betragte sig som staaende i Forældrenes Sted overfor Eleverne. Da først har de fundet den rette Opdragerindstilling overfor de dem betroede unge.

Den her skildrede pædagogiske Holdning vil særligt komme til at gøre sig gældende i Religionsundervisningen. Religionen tilhorer efter Zinzendorfs Opfattelse ikke Forstandens Omraade, men derimod et dybere Lag i Mennesket, nemlig Følelsens, Hjertets Dimension. Religionen kan eller skal derfor ikke læres, men leves og dermed anskueliggøres. Den kan ikke paatvinges, men kun frit fremstilles, fortælles og frivilligt tilegnes. Det vil derfor ogsaa være orkeslost at begynde Undervisningen i Kristendom med en begrebsmæssig Udredning af den ubegribelige Gud. Man skal derimod begynde med at fortælle om hans anskuelige Aabenbarelse i Jesus Kristus, hvilken Evangelisterne beretter og vidner om. Den enfoldige og bekendende Fremstilling af Frelseren som det sande Menneske er Nerven i Religionsundervisningen.

Det er forstaaeligt, at denne "b i be $\mathrm{l} h$ is t or is ke« I ndstilling til Religionsspørgsmaalet maatte fjerne Zinzendorf fra Katekismen. Han gik endda en Overgang saa vidt helt at afskaffe al Udenadslæren. Til Gengæld anbefalede han stærkt at synge med Børnene. "Det er en gammelkendt Sag", siger han, "at Salmesangen er den bedste Vej at bringe de guddommelige Sandheder ind i Hjerterne og bevare dem der.« Hans egen Salmeproduktion var i Overensstemmelse hermed meget frodig og tillige stærkt bibelhistorisk præget. Ligeledes arbejdede han med en ny tidssvarende Oversæt telse af Bibelen i Udtog for Ungdommen, hvori han udelod det for den overflødige og gengav Beretningerue $i$ et for den forestaaeligt Sprog. Han gik den Vej, enhver from Mor vil gaa i Bibringelsen af Religionens Sandheder overfor sit Barn, den historisk fortællende i Stedet for den dogmatisk belærende. Utvivlsomt ubehagelige Minder fra hans egen Barndoms Religionsundervisning lod ham ogsaa en Overgang gøre et Forseg 
med helt at afskaffe Religionstimerne i Skoleundervisningen og lade dem opvejes af Menighedens stille indirekte Indflydelse. paa den opvoksende Slægt.

Zinzendorfs pædagogiske Grundsyn finder sit stærkeste Udtryk i den af ham skabte og for Brødremenigheden særegne Kor-Inddeling. Den er bygget op paa de naturgivne Forskelligheder, som Alder og Køn bringer med sig. "Man skal«, siger Zinzendorf, "efterspore Naturens egen Udvikling og hellige denne.« For Ungdommens Vedkommende inddeler han derefter i følgende $\mathrm{K}$ or-Fællesskaber: 1) de mindste Børn, som henvises til Bornehaven, 2) de skolesøgende indtil Konfirmationsalderen, 3) de større Børn i Pubertetsalderen, 4) de modne ugifte unge, der betragtes som Menighedens Stødtropper. Men alle disse Ungdommens Kor er igen delte paa langs, nemlig efter Kønnet $i$ et mandligt og et kvindeligt Fællesskab, der - af formentlig pædagogiske Grunde - holdes skarpt adskilte.

Denne omhyggeligt gennemførte Korinddeling fortæller os, at Zinzendorf virkelig har studeret de foreliggende fysisk-psykiske Forudsætninger for Opdragelsen og har erkendt $B$ a r nets individuellestadium, dets Væsen og Værdi med alle de Egenskaber - som Enfold, Tillid, Glæde, Aabenhed, Oprigtighed, Ydmyghed, Tilslutning - der er ejendommelige for Barnealderen og Barnesindet. Hans pædagogiske Maal var det nu. at fremstille Jesus som det sandemenneskelige I deal for Børnene og gennem en Vejledning og Tilskyndelse: til barnlig Omgang med Frelseren at fremkalde en vis selvopdragende Aktivitet i Barnet. Eleven skal stræbe efter at blive Menneskebarnet Jesus ligt, idet det følger dette sit høje Forbillede paa det tilsvarende Stadium, hvor det. selv befinder sig. Jesu sande Menneskelighed bliver paa denneMaade det centrale Punkt i Zinzendorfs Pædagogik.

Men lige saa vigtig som Zinzendorfs Opdagelse og Værdsættelse af Barnestadiet og dets gradvise ydre og indre Vækst erhans indgaaende Studium af Overgangsalderens Pubertetskrise med Tabet af Barnets Ureflekterthed og den. 
voksnes begyndende Refleksion, og med de karaktermæssige Forskelle mellem Kønnene, som her aabenbarer sig. Hermed stilles atter nye og særlige Krav til Opdragelsen, ikke mindst den religiøse. Zinzendorf var - sikkert af egen personlig Erfaring - fuldt klar over det seksuelle Elements store og afgørende Betydning i Menneskets legemlige og sjælelige Udvikling og dermed ogsaa for Opdragelsen. Intet pædagogisk Enkeltspørgsmaal har han viet saa megen Eftertanke som dette, hævder Uttendörfer. Han havde set, at den seksuelle Modning løber parallelt med den religiøse Udvikling, og at disse to vigtige Omraader i Menneskets Følelsesliv gensidigt øvede en frugtbar og bevarende Indflydelse paa hinanden. Det er jo i denne kritiske og svangre Alder, at Syndsfølelsen normalt vokser frem og Personlighedens religiøst betonede Gennembrud finder Sted. Men Zinzendorf havde under'sin egen pietistiske Opdragelse ogsaa oplevet, hvor forstyrrende og ødelæggende forkvaklede Forhold paa de her nævnte to Omraader kunde gribe ind i unges Udvikling. Særligt paa dette Punkt gjaldt det for ham at overvinde det pietistiske Trang- og Fejlsyn. Pietismen bedømte jo de seksuelle Ungdomssynder særligt strengt, ja ansaa dem endda som Hovedsynden, fordi man opfattede Kønsdriften som syndig i sig selv. Og desaarsag drev man paa Askese, der nødvendigvis endte' $i$ en eller anden Lovtrældom. Heroverfor fremstillede Zinzendorf det seksuelle som noget naturligt og helligt, som en Guds Gave, der skulde forvaltes ret og bruges til Velsignelse. Han henviste igen til Mennesket Jesus som den, der ogsaa havde oplevet "Mandvordelsens Krise«, og understregede samtidig de Pligter, man havde overfor sit Legeme som Helligaandens Tempel. At den for Brødremenigheden ejendommelige og :regelmæssige private Sjælesorg ogsaa paa dette vanskelige Punkt i Ungdomsopdragelsen maatte faa sin store Betydning, maa anses for givet.

At Pubertetskrisen i Regelen forløb mindre stormende for de unge Pigers Vedkommende, var Zinzendorf paa det rene med. Han krævede en hertil svarende Vejledning af disse, som var 


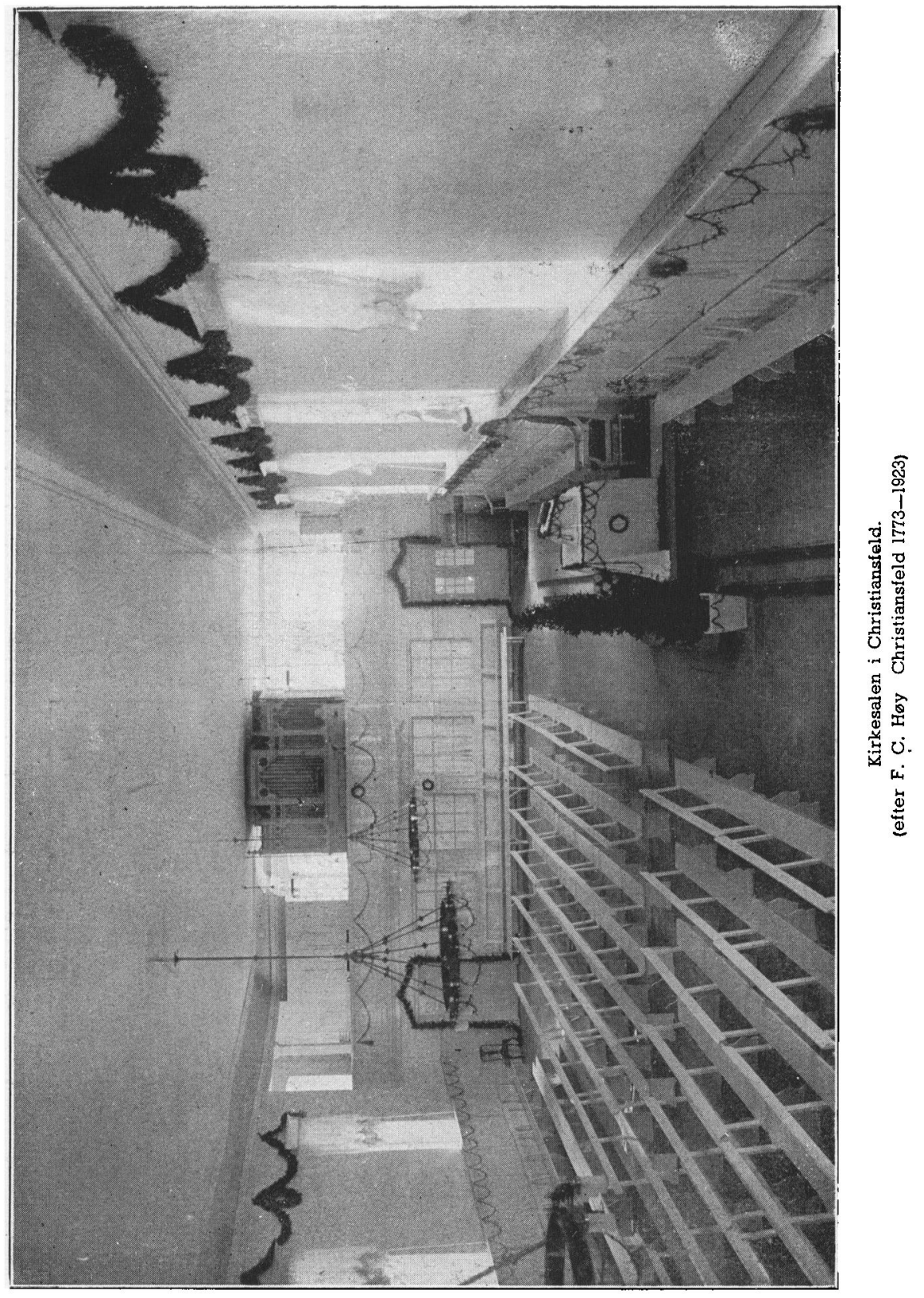




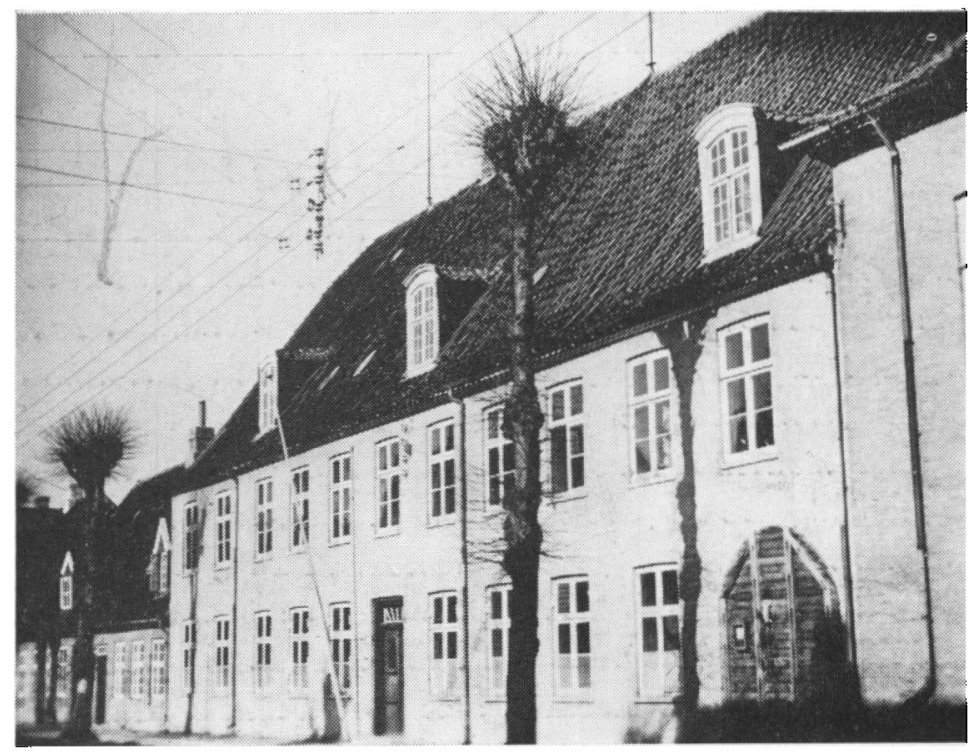

Drenge-Kostskolen omkr. 185n.

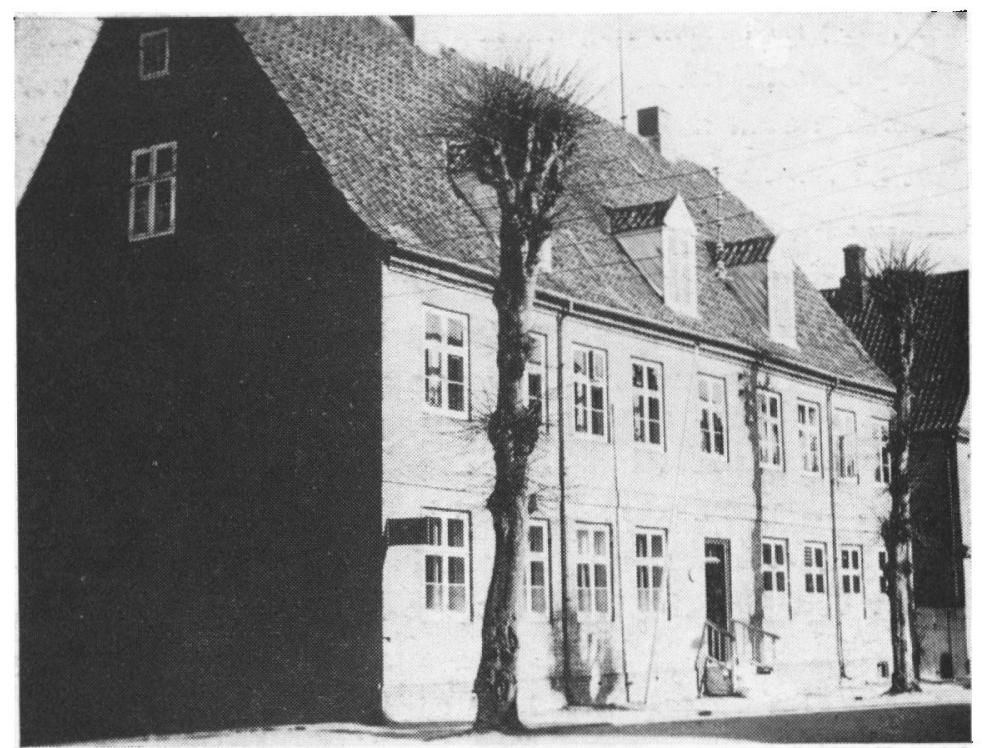

Pige-Kostskolen omkr. 1850. 
overdraget de særlige kvindelige Sjælesørger,e, der stod i Spidsen for de kvindelige Korfællesskaber. I denne Sammenhæng tilkommer det Zinzendorf historisk den Fre, maaske som den første indenfor Protestantismen, konsekvent at have hævdet Kvindensevangeliske Ligeberettigelse med Manden og hendes individuelle Naadegave indenfor Menighedens Liv og Virke. Han har i udstrakt Grad anvist de kvindelige Medlemmer af Menigheden deres specielle Tjeneste indenfor denne som Børneopdragersker og Sygeplejersker, det nytestamentlige Diakonisseembede, hvilende paa det helligede Moderinstinkt.

Mall har kaldt Zinzendorf en Ung dom mon s B efrier i sin Tid. Den foregaaende Fremstilling har vel i nogen Grad kunnet underbygge denne Dom. At han havde dygtige og selvstændige Medhjælpere og Fortsættere i Opdragergerningen, skal endnu lige nævnes. Det var egentlig forst efter Zinzendorfs Død, at Skolegerningen fik sin Blomstring indenfor Brødremenigheden og drog de mange Elever til udefra. At dens faktiske Niveau ikke altid naaede op paa Højde med det af.Zinzendorf inspirerede Ideal, maa villigt indrømmes, især da Idealets fulde Virkeliggørelse i saa høj Grad afhænger af de enkelte ansatte Opdrageres personlige Kvalifikationer. Men Viljen var god nok og Linjen var ogsaa den rigtige, og derfor Tilslutningen heller ikke ufortjent. Vi møder. i Herrnhuterskolen e.n Men ig he dsskole i ophøjet Betydning, en evangelisk Klosterskole med en Opdragelse, der i lige høj Grad bygger paa de naturlige.menneskelige Forudsætninger hos Eleven som paa Aandens, frie og skabende Gerning i Mennesket. Det herrnhutiske Skolesyn kan ikke karakteriseres mere rammende end med det Udtryk, Grundtvig har givet for sit folkeopdragende Syn i sit. bekendte pædagogiske Digt til sine Børn om "et jævnt og muntert, virksomt Liv paa Jord«. Ogsaa de herrnhutiske Opdragere i Christiansfeld og andetsteds arbejdede i Forvisningen om, "at Lykken svæver over Urtegaarden, naar Støvet lægges i sin Skabers Haand, og alting ventes i Naturens Orden.« - - 
V.

\section{Elev-Indtryk fra Christiansfeld.}

Det er kun sparsomt, hvad der kan opspores angaaende Elevernes Indtryk fra deres Skolegang i Christiansfeld. Et fornemt litterært Dokument ejer vi $\operatorname{dog}$ i Camilla Collets indgaaende Skildring af sit Christiansfeld-Ophold 1827-29 i den allerede berorte selvbiografiske Bog "I de lange Nætter", Side 89129. Skildringen er dels sympatisk, dels ret kritisk. Hun selv mener ikke at have haft noget særligt Udbytte af Opholdet ("kom jeg lige saa klog ud af Institutet som jeg havde betraadt det", skriver hun), medens derimod et Venskab, hun sluttede med en Med-Elev, der døde et Par Dage efter sin Konfirmation, kom til at staa for hende i Mindets skønneste Glans.

"Der ligger saa meget godt og hæderligt til Grund for denne Anstalt", skriver hun videre, "som man vel skal vogte sig for at miskjende, men det gjælder om denne, som om alle af den Art, at den ikke passer for alle; den magter ikke, ligesaalidt som nogen Skole, hvor Opdragelsesforretningen drives en gros, at yde enhver Individualitet, enhver Skæbne sin særskilte Forpleining. For mange Naturer kan den maaske være en beroligende, højst velgjørende Overgang til det Liv, de siden ville føre, og jeg har hørt netop verdslig opdragne Børn prise den rolige Tid i Christiansfeldt som den lykkeligste $i$ sit Liv. For mange ulykkelige Born har det været en velsignet Havn, hvor de undertiden har slaaet sig til Ro for Livet. For mig var det Afsondring, Ensomheden kun i en anden, klosterligere Form end den, jeg havde været vant til. Men Meningen or jo ikke, at man skal indvies til at gaa i Kloster, men til at færdes i Verden bagefter. Man skal lære at kjende sig selv og sine Anlæg og Kræfter, og hvorvidt de due til at træde op i de Kampe, der ikke længe lade vente paa sig". -

Særligt har hun, der hjemme fra var svagelig af Helbred og sky af Væsen, været trykket af et Par københavnske Med-Elevers stille Tyrani overfor de andre paa samme Stue, medens 
saa til Gengæld Venskabet med den allerede omtalte Stuekammerat, Datter af en dansk Officersenke, gav hende fuld Oprejsning for alle smaa Ubehageligheder. Hun forlod da ogsaa Christiansfeld "med en Skat af lyse Minder, som aldrig kunde forsvinde. I Christiansfeldt har jeg truffet paa saa herlige, $i$ sin Art fuldkomne Mennesker.»

Med Glæde mindes hun ogsaa »Gudstjenesten, der i sin ædle Simpelhed ikke kan være smukkere og mere opløftende end hos Herrnhutterne." - -

Kirkehistorikeren F. Hammerichs Moder, Meta Magdalena Adolph fra Nolde i Burkal Sogn, var fra sit sjette Aar (1783) opdraget i Christiansfeld. Sønnen er stærkt afvisende overfor "Kristjanfelter Væsenet«, som han udtrykker sig, skønt han tillige maa indrømme, at en Nadverdeltagelse $i$ Christiansfeld for ham blev ved med at staa som noget af det rigeste, han havde været med til. Af sin Moders Opdragelse i Herrnhuterbyen, hvor hun ogsaa indgik sit første Agteskab, giver han i sin Selvbiografi "Et Levnetsløb« (S. 19-20) følgende Skildring: "Meta Magdalena var virkelig et særsyn i sine omgivelser, og kun den ærlige fromhed havde hun til fælles med dem. Hun var et sanddru menneske og en varm sjæl, og hun hørte til disse oprindelige naturer, der vugges i stemninger og følelser, disse i grunden digterske naturer, hvor livet altid sprudler frem som af en frisk kilde, de ved ikke selv hvorledes. Det røbede sig i den ranke holdning, det aabne, naturlige væsen, det sjælfulde aasyn, og hjærtensgodheden lyste ud af hendes øjne. Let blev hun hastig, men, saa hed det blandt veninderne: "havde hun bare faaet smækket døren i, var hun god igen.« Med en takt, en ynde, som var hun opdragen $i$ de fineste kredse, traadte hun enhver i møde, og der laa alligevel i hele personligheden noget vist overlegent.

Hun havde en lys forstand og vidste at skaffe sig en dannelse, man efter forholdene i Kristjansfelt maatte undres over, ogsaa en fin smag. Tysk havde hun lært godt, skønt hun ikke undgik danske ord og vendinger og man paa udtalen straks 
mærkede den fremmede. Hun kændte ikke blot til de bædste tyske digtere, men selv til Shakespeare... Hun broderede, hun tegnede nydeligt blomster og malede dem, hun sang, hun spillede baade paa klaver og harpe og forstod at lægge sjæl i spillet. .... Og hun havde mange veninder, danske, tyske, norske, svenske, alle de sprog finde vi mellem hinanden i hendes stambog og brevsamling. Ti lige saa elskværdig hun var, lige saa trofast en sjæl, "altid tankefuld «, sagde en anden veninde, "sjælden lystig, men altid glad «." Saavidt Hammerich. -

Sømnen holder det aabenbart for opportunt at hævde, at Moderen er opvokset $\mathrm{i}$ et vist Modsætningsforhold til det "trangbrystede" og "snæversynede" i hendes Omgivelse i Christianfeld, hvor hun iøvrigt boede indtil sit 31. Aar. Det ligger dog ulige nærmere at antage, at hendes fribaarne, adelige Sind netop er blevet dannet under Indflydelse af den evangeliske Aand, der omgav hende i de afgørende Vækstaar. Hun har været en fuldgod Herrnhuter, selvom dette ikke var god Latin paa Bjerget. -

Jakob Hansen $\mathrm{K} l$ o p p en b u r g, Plejesøn af Tingskriveren i Gram, sendtes 1802 (ikke 1800, som han selv opgiver) efter Moderens Død og Faderens nye Giftermaal til Opdragelse i Christiansfeld. Han bortvistes dog efter et Par Aars Forløb - mod Faderens Ønske - fra Skolen paa Grund af "Opsætsighed». I sin Selvbiografi "En gammel Soldats Erindringer«, 1861, nævner han kun, at han har været paa Stedet, men intet om sine Indtryk. Derimod fortæller han, at Lysten til at blive Soldat vaagnede i ham i disse Skoleaar, nemlig ved at se Forbimarschen af Tropper paa Kolding-Haderslev Vejen. Ogsaa Kronprinsen saa' han tage ind paa Menighedens Gæstgiveri. - - -

I Christiansfelds Skolearkiv findes en Del Breve fra E lever, skrevne efter Hjemkomsten fra deres Ophold paa Skolen som en Tak for det, de havde modtaget paa Stedet. Indholdet af disse Breve er - som venteligt paa det paagældende Alderstrin - ret uselvstæendigt og stereotypt, delvis foraarsaget af det fremmede (tyske) Sprog, de skulde benytte sig af. Et 
Par Udtalelser skal dog anfores som Eksempler paa Christiansfeld-Opdragelsens Frugt i unge Sind.

Gustaf $L$ ef $\mathrm{f} l \mathrm{er}$, Grossererson fra Göteborg, indleder et Brev 16. 10. 1799 saalunde: "Da ich nun die Ehre habe Ihnen zuzuschreiben, so soll mein erstes sein, meinen Dank wegen der in den 5 Jahren an mir gewandten treuen Pflege abzustatten.. «.

Gustaf v. Snoils k y, Grevesen fra Stockholm, der voldte sine Opdragere mange Vanskeligheder, takker alligevel med følgende konventionelle Ord: "....Gewiss werde ich nie Christiansfeld, nie die herzlichen und freundschaftlichen Ermanungen zum Fleiss und zur Tugend die ich da so oft und wiederholt bekam vergessen, und ich werde mich immer bestreben diesen Ermahnungen aufs beste nachzuleben....

N. W. v. Da h l cron a, Stockholm, skriver 4. 4. 1800 lidt vemodigt om Sømmen Georg, der efter Skolegang i Christiansfeld havde begyndt at studere i Niesky, men saa onskede at fortsæt: te Studierne hjemme i Sverige: "....Hans framsteg i vetenskaper ock i synnerhet i språken äro så stora, at han i Upsala, dit jag sjelf sände honom for ett par månader sedan, vid sin examen giorde just stor uppmärksamhet, ock gaf heder åt Brödre Scholorna, som jag för Professorerne helt ouvert gaf tillkiänna at han studerat uti. Då fins ingen adelsman i Hela Sverige, som är så kunig i Graekiskan ock Haebraiskan som han, ock nu lärer han sig Syriskan ock Arabiskan till, men detta alt smickrar mig ingonting, om den vishet, som kommar ofvan efter å sido sättas....u. -

Maaske er det denne Elev, som Societetsforstander Warnke i Stockholm mødte som Professor $1825 \mathrm{og}$ af hvem han fik det Svar, at han ønskede, han aldrig havde været i Christiansfeld. Det samme Svar, W. Aaret forud havde faaet af en velhavende Konsul i Frederikshald i Norge. -

Maaske havde Pigerne lettere ved at falde til. Det gælder f. Eks. for Anne S c h u m a ch er fra Nordborg, om hvem Faderen efter hendes Hjemkomst beretter 12. 10. 1801; at ".... meine Anne die Annehmlichkeit ihres dortigen Aufenthalts nicht genug 
rühmen kann, und nie beredter ist, als wenn sie von Christiansfeld spricht. Sie wird lebenslang Ursache haben, für die gute Erziehung und nachsichtsvolle Behandlung, die sie dorten genossen, dankbar zu sein...... -

Men ogsaa Drenge kunde mindes deres Christiansfeldtid med Taknemlighed og endda forstaa at give denne et herrnhutisk Tilsnit. Det gælder saaledes Petter $\mathrm{H}$ e d m a n, Grosserersøn fra Göteborg, der skriver tre lange Breve til Husfader Senft ved dennes Forflyttelse fra Christiansfeld til Gnadau. Han skriver 3. 3. 1810: "Inniggeliebter Freund und Bruder.... Zu ihrem Ruf nach Gnadau gratulire ich übrigens recht herzlich, und wünsche, dass der liebe Heiland sie glücklich an den Ort ihrer Bestimmung führen wolle, und dass sein Seegen in so vollem Masse über sie ruhen wolle, dass ihnen Augen und Mund davon übergehen. Der liebevolle Heiland, der gute Hirte, tröste sie recht innig über dem Vorgange und öfne ihnen eine lachende Aussicht in die Zukunft nemlich: wie ein Bienelein immer an Jesu Rosenwunden zu saugen. Ach lieber Bruder! Wie schön muss das nicht sein. Ach beten sie für mich, dass ich zu dieser unbeschreiblichen Gnade gelange, und dass der Heiland mich armen würdigen wolle, meine Seele ganz zum Tempel der Dreieinigkeit einzurichten. Ach wie Seelig würde ich dann hier in dieser verdorbenen Welt leben in alle Tage, meinen Heiland lieber gewinnen, gern auf das übrige mit Scheu hinblicken.... «. -

Den 14-15aarige Arnoldine L u n d fra København former sit Nytaarsønske overfor Sønnichsen i følgende Ord (30.12.1817): ".... Ihnen, der in vier Jahren meines Lebens mein gütiger zweiter Vater gewesen ist, zu schreiben, und Ihnen aus einem vollen dankbaren Herzen zum neuen Jahre zu gratuliren, ach die Jahre, da Sie mein Vater waren, werden villeicht, ja wahrscheinlich die vier glücklichsten meines Lebens gewesen seyn, darum werde ich stets mit tiefer Rührung daran denken...... -

v. Astrup, København, hvis Datter Caroline gik i Christiansfeldskolen, sender endda en versificeret Nytaarshilsen til Sønnichsen (1821): 
"Dem, Gartner i den skiønne Have, hvor Ungdom elskes op til Dyd, For hvem det er den bedste Gave, For hvem det er den største Fryd, At disse ædle Frugter trives, At skiønne Blomster spirer frem Retskafnes beste Løn Dem gives! Det, skiønsom Fader onsker Dem!! -

Sognepræst B i r c h, Vedersø, skriver paa den hjemvendte Datter Hansines Vegne 28. 6. 1821: "....Hansine befinder sig nu ganske vel, da hun ved det ikke kan blive anderledes. Rigtig nok forlod hun Christiansfeld med et tungt Hierte, som var saa naturligt, da hun dermed tillige maatte forlade saa mange gode, kiære Venner; rigtig nok vil der imellemstunder opstige nogle mørke Skyer paa Panden, naar Christiansfeld kommer i Tankerne, men vi sorger for paa bedste Maade at faae dem hastig fordrevne, at de ikke skal give Regn fra sig, og det kiære Christiansfeld vil vel næppe nogensinde forglemmes af hende, og det var heller ikke smukt, da hun der har nydt saa mange kiære Øieblikke, som kan blive hende til megen Glæde og Gavn i hendes ganske Liv, jeg har derfor den Are paa hendes Vegne ærbødigst at hilse Dem og høistærede gode Familie med hendes ovrige gode Venner fra hende, og aflægge til Dem alle hendes forbindtligste Tak! —"

I Aaret 1825 fejrede Skolen sit 50-Aars Jubilæum. I den Anledning forfattedes en Kantate, som ogsaa sendtes til Skolens tidligere Elever. Marthe Sorterup, Vinhandlerdatter fra Næstved, der sammen med fire yngre Søskende havde gaaet i Skolen, siden var blevet gift med Apoteker Møller paa Vesterbro i København, og nu sad som ung Enke med fire Drenge, sender herfor en varm Tak til Sennichsen, hendes "Vejleder i Ungdommens Aar, og særligt til Lærerinde Søster Crøger, "thi under hendes gode Vejledning lærte jeg først rigtig at vælge det rette og gode«, skriver hun.

Blandt andre, der takker for den tilsendte Kantate, er Silkegrosserer A. F. T u t e i n, København, og Købmand J. K ra - 
$m$ er, Tønder. Den sidste mindes som én af de 988 Elever, der i de forløbne 50 Aar er blevet opdragne i Christiansfeld, baade visse smaa Ubehageligheder, men særlig som det vigtigste to Opdrageres gode Udsæd i hans unge Hjerte. Det var Mathias I versen fra Lydersholm og Christian $\mathrm{H}$ ans en fra Esmark i Angel. Den første har i fortrolige Samtaler paa Spadsereturene haft stærk Indflydelse paa ham, den anden har i Bibeltimen Onsdag Formiddag med Varme lagt Eleverne det ene forngdne paa Sinde. Og det afgørende for ham blev, at disse to Herrnhutere viste sig i Sandhed selv at høre Kristus til. - Altsaa her som overalt det levende Eksempels bestemmende Magt!

Blandt de Elever, der døde under deres Ophold i Christiansfeld, var Julie v. A s t r u p, om hvem Faderen skriver 4. 7. 1826: "... Min lille elskede Julie fandt en Grav hos Dem, paa et yndigt Sted, og en Forberedelse til sin Hjemgang, der skjankede hendes barnlige Sjæl en Modenhed, som var mærkelig for hendes Alder..... -

Vartovpræsten C. J. B randts Forældre i Nyborg havde begge besøgt Skolen i Hermhuterbyen. Moderen, Louise, født Boesen, fra Vigerslev Præstegaard, skriver herom 28. 6. 1829 til Sønnichsen: ".... Med den varmeste Længsel, dog engang igien at kunde, til Opmuntring og Velsignelse for mit Hjerte, giøre et Besøg i det kiere dyrebare Christiansfeldt, beder jeg herved paa det oprigtigste undertiden i Kierlighed at maatte erindres af Dem og Deres....«. Og Faderen, Købmand Peter Brandt, regner det ved Bedstefaderens, Svendborgkøbmanden Hans Caspar Brandts Død i 1840, til Børnenes fornemste "Arvedel«, at de alle er blevet "opdragne i den kære Menighed«. (Brev 29. 9. 1840 med Meddelelse om Faderens Død).

Erasmus J. P e t ers en, Sen af den kendte Stænderdeputerede i Dalby, viser sin Sprogfærdighed ved at sende et Brev paa Fransk til sin gamle Lærer, Pastor Roentgen (24. 10. 1840).

Til Slut skal meddeles (i Oversættelse) en Fodselsdagshilsen til Roentgen fra Anna F ri c k, Horsens, der 18. 12.1847 paa korrekt Tysk takker sin Lærer for al Omsorg i de to Aar, hun 
var i Christiansfeld. "...AAh hvor ofte tænker jeg ikke med Længsel paa Christiansfeld, paa de dejlige Undervisningstimer, hvori De opmuntrede os til at elske Jesus over alt andet...... Hun vil henregne Aarene paa Skolen til de lykkeligste i sit Liv og særligt mindes Juleaften i Christiansfeld. "....Aldrig har jeg oplevet skønnere Jul end i Christiansfeld, de Tusinder af Lys Juleaften, hvilket skønt Sindbillede er de ikke paa, at der var Mørke og Mulm i Verden, men Kristus blev fodt og bragte Lys......

VI.

\section{Skolens historiske Betydning.}

En saa særpræget Skole, som Opdragelses-Institutet i Christiansfeld var det, maatte ove sin Indflydelse i Tiden. Jeg skal nu forsøge at give en Vurdering heraf under et tredobbelt Synspunkt, nemlig et religiøst, et nationalt og et pædagogisk ogherunder særlig have Skolens snævrere Opland Nordslesvig i Tankerne.

1. Da Kolonien og Menigheden Christiansfeld i Slutningen af det 18. Aarhundrede skød frem som en Kvist af tør Rod her i vore Lande og tiltrak sig Opmærksomhed fra hele Norden, var det utvivlsomt den der oprettede Skoles gammelkristelige Grundsigte, der gav Institutet Præg og Navn. Det var et Slags. evangelisk Kloster, en statsfri Menighedsskole, som pietistisk vakte Hjem med Tryghed kunde betro deres Børn.

I et Udkast fra 1774 til den kommende Skoles Undervisningsplan siges der om dette Skolens kristelige Grundsigte: "Hos samtlige Barn skal intet spares, hvorved de kan tilskyndes til at overgive sig til Herren, der med sit dyrebare Blod har købt dem til sin Ejendom", og man venter at modtage "haabefulde Born med det Vidnesbyrd, at Helligaanden arbejder paa deres. Hjerter."

Blandt de Forældre her i Nordslesvig, der sendte Børn til Opdragelse i Christiansfeld, var - som allerede nævnt - den kendte Tingskriver J a c o b K l o p p e $\mathrm{n} b$ u r $\mathrm{g}$ i Gram. Han var- 
Pietist og giver i Anledning af sin Plejesøn Jacob Hansens Optagelse i Institutet (i Brev paa Tysk af 13. Marts 1802) en Skildring af sin "Hjertetilstand", som vel ogisaa kan have en vis personalhistorisk Interesse. Han har haft lidt Vanskelighed med at acceptere den opgivne Pensionspris fra Christiansfeld, "da Barnet ikke er vort eget«, men har nu alligevel bestemt sig, og skriver saa:

"Hvad Omkostningerne angaar, da skal disse jo ganske vist tages i Betragtning. Men paa min Side volder det ingen Vanskelighed, da jeg med alt, hvad jeg er og har, betragter mig som Frelserens Ejendom. Paa den Maade er jeg kun Husholder over det, som Han har givet mig, for at jeg skal bruge det til Hans Eres Pris og til Gavn og Tjeneste for mine Nærmeste og Medmennesker, især Hans Menighed; Hans Fjendomsfolk. - Thi intet kan glæde mig mere end Hans Folks Berømmelse, og intet hedreve mig mere end dets Forsmædelse. hvori jeg inderligst tager Del. - Han Selv er Hans kære Menigheds Hoved. - Og naturligvis, naar Hovedet lider, da lider alle Lemmerne med. Han er alene Hjertekenderen, der gennnemskuer og kender os alle som $i$ et Spejl, at end ikke den ringeste Kærlighed til denne Jords Ting, hvad Navn de end monnne have, ingen Tilbøjelighed i vore Hjerter forbliver skjult for Ham, og derfor stiller jeg mig saa villigt, aahent og uden Forbehold frem for Vor Herre. Ganske vist kommer derved kun Elendighed og Skrobelighed for Lyset; noget godt i $\mathbf{H ~ a ~ n ~ s ~}$ o j n kender jeg ikke. Men ogsaa i al min Elendighedsfølelse, naar jeg intet skjuler for Ham, aabenbarer Ham alt, og forraader Fjenden snart her og snart der, ser og mærker jeg Hans Nærværelse; intet kan vederkvæge og opmuntre mig med rigere Trøst end Han, netop i den Situation. Derfor er jeg altid vel til Mode, men helier ikke længere, end jeg forbliver $i$ dennne Hjertestilling overfor Ham.

Se, kære Broder, det er min Hjertetilstand!.... « -

Det er forstaaeligt, at de pietistiske Kredse i Nordslesvig og andet Steds, som Kloppenburg her repræsenter paa saa agte og smuk en Vis, hilste Skolen i Christiansfeld velkommen. Men Skolen selv laa, som jeg har provet at vise det i det foregaaende, ikke helt paa den pietistiske Linie, men paa en religiøst og menneskeligt friere. Den maa derfor ogsaa antuges som Helhed at have virket $i$ en friere Retning og have opdraget en Slægt, som var religiest mere frigjort end Fædrene, uden at miste Religionens dybe Rodfæstethed. 
Men Eleverne gik jo ikke blot i Skole, men havde ogsaa deres midlertidige $\mathrm{Hjem}$ i Christiansfeld. Og der maa regnes med, at der blandt disse jævne Stue-Brodre og -Søstre, som Børnene var betroet til udenfor Skoletiden, fandtes mere snæversynede Mennesker, som kan have virket religiøst forkvaklende ind paa unge Sind. I en Protokolanmærkning allerede fra 1786 hedder det saaledes, at en bestemt Stue-Foresat (hvem Børnene jo paa sin Vis var prisgivet $i$ godt som $i$ ondt), "venligst skal paamindes om, at han i sin Omgang med Børnene maa tage sig i Agt for alt snævert og lovmæssigt, og ikke gennem for megen Prædiken og Forelæsning af gudelige Skrifter maa gøre Børnene enten til Hyklere eller bibringe dem Afsmag overfor Hjerteanliggender«. Denne Mand har altsaa vist Nidkærhed uden Forstand og ikke behandlet sine undergivne med den psykologiske Sans for Barnet, som Zinzendorf havde anvist.

Naar Christiansfeld blev uforglemmelig for nogle Elever, medens andre siden hen kunde onske, at de aldrig var blevet sendt til dette Sted, da er det sikkert Koloniens hele religiøse Atmosfære, der har skilt Vandene i Bornenes Sind. Den har været stærk og indtrængende, næppe paatrængende, med sine daglige Andagter og religiøse Øvelser. Bl. a. skulde de daglige Løsenstekster læres uden ad af Børnene. Men den rigelige Brug af Salmesang maa til Gengæld have tiltalt Barnesind og have afbalanceret det religiøse Indtryk. For nogle blev ChristiansfeldReligionen da en afgørende Hjælp for Livet, for andre betød den sjælelig Vold og paafolgende Foragt for mKristjansfelterVæsenet«. Men som Helhed vil jeg tro, at f. Eks. den svenske Baronesse Regina de Fleetwood, født v. Köhler ikke er blevet skuffet, naar hun (i Brev til Christiansfeld fra 1799) ventede, at hendes Søn i Herrnhuter-Skolen »ikke just skulde blive en højlærd Mand, men en retskaffen Kristen og et gavnligt Medlem af Samfundet«. - Herrnhuterne har med Rette haft IOrd for paa helhjertet Vis at "give Gud, hvad Guds er, og Kejseren, hvad Kejserens er». Og derfor har deres Skoler uden 
Tvivl ogsaa fostret mange "Mænd med faste Hjerter" og "[romme, stærke Kvinder". Jeg har selv mødt en Del af disse i Nordslesvigs Sogne.

2. Om Skolens nationale Betyduing kan der forst blive Tale sammen med Nordslesvigs nationale Vækkelse i Midten af forrige Aarhundrede. Det gik da i denne det nationale Valgs Tid, som det efter Skolens tyske Oprindelse og stadige tyske Forbindelse ikke kunde ventes anderledes. Ledelsen stillede sig paa tysk Side. Dens daværende anerkendt dygtige Inspektør, Pastor Ro en t ge n, maatte efter hele sin Fortid tage Parti for Tyskheden i Grænselandet. 1839 indforte han militære Øvelser i Skolen, som om han anede den kommende Udvikling af Tingene.

Det viste sig da ogsaa fortrinsvis at være hjemmetyske Hjem i Nordslesvig, som under Roentgens Inspektorat i stigende Tal sendte deres Børn til Christiansfeld. Et typisk Udtryk for disse Kredses Indstilling giver vel et Brev fra Gaardejer P e d e $\mathbf{H}$. $V$ in t e r i Søndernæs, Brøns Sogn. Han skriver (8. 8. 1845) med Henblik paa Sønnens Ophold i Christiansfeld, der forresten under ingen Omstændigheder ønskes forlænget ud over Konfirmationsforberedelsen (paa Tysk), bl. a.:

\section{Kjere Her Pastor Röntgen!}

.... Det giorde mig hierteligt Ondt, da jeg besøgte Dem Her Röntgen! at jeg ikke kunde tale Tydsk med Dem ang. min Søn. Hvad der egentlig laae mig paa Hiertet at tale med Dem om var, at han faar lært saa meget som muligt de toe Punkter, nemlig det første at han bliver bekiendt med Frelserens Sag, hvad han har givet, da hans Kierlighed drev ham i Døden for os, og om vort fordærvede Hierte og den Fare et ungt uerfarent Hierte svæver i, naar han ikke vil lade sig bevare af ham, det andet er det Tydskesprog, som han skal overhøres i til næstkommende Paaske. Du tager mig ikke ilde op, at jeg gientager dette Ønske, som er min og min Families Hovedbegiering. Forøvigt dersom han skulde have tilovers fra disse toe Hovedpunkter, da er det os meget kiert at han lærer andre Videnskaber ved Siden af......

I et senere Brev (26. 11.) gentager Faderen sit Ønske om at faa Søunen hjem til Konfirmationen (paa Dansk). Eventuelt kunde han efter Konfirmationen fortsætte paa Skolen til Juli, 
ogsaa "gierne slippe Tegning og alt anden Lærdom, naar han maatte kun blive ved det Tydskesprog og Relligion«, men siden (til Høhøsten) skal han hjem og "være Bonde«. - -

Hjemmetyske Bønder, som - af økonomiske Grunde - havde valgt Bejleren fra Syd, var hjælpeløse, naar det gjaldt den Trolovedes Sprog, men nu skulde deres Børn ikke længere være "Bondepige o og skamme sig over deres foragtede Modersmaal, men lære "tyske Frøken"' ens »fine" Sprog i Christiansfeld, saa de kunde klare sig "ved Hove«.

Mellem Krigene var Christiansfeld den eneste tyske Skole i Nordslesvig, hvorfor den ogsaa fik stigende Sogning fra tyske Hjem i Nordslesvig, der her kunde faa deres Børn underviste og konfirmerede paa Tysk. I Skolens Aarsoversigt fra 1852 klages der over, at tre dygtige Lærere - foruden Inspektøren selv - har maattet forlade Byen og Skolen, efter at de "i en Aarrække har haft Tjeneste i Institutet og vundet baade Forældrenes Tillid og deres Elevers Kærlighed,.... tilmed da de af Erfaring kendte Forholdene her i Landet og i denne Tid var udsatte for politiske Forfølgelser, der udgik fra ejderdanske Civilembedsmænd og Gejstlige, for hvem vore tyske Instituter i det danske Nord Slesvig er en Torn i Øjet." - Ogsaa to andre tro og dygtige Lærere gik Syd paa efter Slesvig-Holstenernes Nederlag 1850. I to folgende Aars Oversigter (1854 og 55) siges det dog udtrykkeligt, at "man i det forløbne Aar ikke har lidt under politiske Forfølgelser«. Skolen havde jo i 50'erne en Københavner til Inspektor.

Efter 1864 blev Christiansfeldskolen under dens nye Ledere et villigt Redskab for de tyske Bestræbelser i Grænselandet. 1867 nedskriver Inspektøren i sin Aarsoversigt følgende betegnende Overvejelse: "Under den nuværende Uvisheds Tid vil der ikke være meget at gøre, men hører denne op, og Nordslesvig forbliver hos Preussen, da maa Christiansfeld efter min Mening endnu mere end hidtil antage Karakteren af et tysk Institut." Aaret efter faar hans Drømme et endnu mere konkret Udtryk: "En tỵsk Skole for Nord Slesvig, hvis Elever fores frem til Eks- 
amen for ét-aarig-frivillige,") det var et Program, for hvilket Jeg vilde arbejde med stor Kærlighed, selvom Pensionatet ved Siden af var meget lille,... med ét Maal for alle, nemlig tysk Sprog og tysk Dannelse. Ganske vist kan saa ved Siden heraf ikke ogsaa dansk Sprog dyrkes. E et S p r og maa være Hovedformaalet, og alle andre underordnes dette og gælde som fremmede Sprog. - Saadan er det nu med det danske. Det staar paa samme Linie med Engelsk og Fransk." -

Da Nordslesvigs Skæbne saa foreløbig blev afgjort ved Preussens Sejr over Frankrig, der ogsaa i Christiansfeld opfattedes som »en Guds Dom" og "en Løftestang til Guds Riges Opbyggelse i de store Dimensioner", foranstaltede Ledelsen den 30. Januar 1871 »en Glædesfest for Paris' Kapitulation« og angav dermed den fremtidige Kurs. Fra Nordens Lande ventede man nu ikke flere Elever, idet "den franske Krigs Resultater har fyldt samtlige Skandinaver med Had og Forbitrelse mod Tyskland«. Til Gengæld syntes der at aabne sig en Dor for Skolen blandt "Albions Sønner", som man foretrak fremfor Nordslesvigs Bøndersønner med deres "ubehøvlede Væsen" og "stæ̈rkt materielle Interesser".

Man var glad for, at de nye preussiske Myndigheder forelobig helt undlod at blande sig i Skolens Anliggender, efter hvad man - ikke med Urette - formodede, fordi "vore herværende Instituter nær ved den jydske Grænse er velsete af Regeringen paa Grund af vor germaniserende Indflydels e paa Omegnens landlige Befolkning". Af Hensyn til enkelte nye danske Elever vil man dog fremhæve, at Institutet »ikke befatter sig med Politik « og fremdeles ogsaa vil hævde sin winternationale Karakter« (1874). 1879 havde man endnu intet mærket til "Statens Indblanding i vore Skoleanliggender". Først 1889, efter Udstedelsen af den berygtede prøjsiske Skoleanordning af 18. December 1888, mødte Skoleraad S a s s fra Regeringen i Slesvig

-) Tysk Betegnelse for Realeksamen, hvis Absolventer havde Privilegium paa kun ét Aars, frivillig Militærtjeneste, hvorefter man blev Officersaspiranter. 
sammen med Kredsskoleinspektør S t e g e l man n fra Haderslev op i Skolen og stillede Krav om prøjsisk Ensretning. Dermed var Skolens Karakter af "international « Kostskole forbi. ForFremtiden rangerede den paa Linie med andre offentlige tyske Realskoler i Grænselandet, hvis fornemste Opgave det var at fremme tysk Sprog, Kultur og Sindelag blandt Landets opvoksende Slægt, især den fra Landbefolkningen. Man var blevet en "helt igennem tysk Skole«, der gik Statens Arinde mod den danske Befolknings Ønsker, efter Sigende dog ikke med den. ovrige Menigheds udelte Tilslutning.

3. Pædagogisk var Christiansfeld-Skolen utvivisomt lidt af et Særsyn i Tiden. Aand og Metode i dens Undervisning harmonerede ingenlunde med den gamle "sorte Skole", dens Foragt. for Modersmaalet, Brug af Riset, Katekismelærdom og Eksa-mensterperi, og ligesaa lidt med den nye preussiske Skole, dens. militære Sigte og statslige Tvang. Tværtimod, man var i Pagt. med Brødre-Biskoppen Amos Comenius' aandsbestemte og naturgroede pædagogiske Principper og dermed et godt Stykkeforud for sin egen Tid og Omgivelse.

Dr. E. Kaper, den kendte Skoleborgmester, hentyder her til i en lille Udtalelse, fremsat i Aarsskriftet 1937 for den nuværende Christiansfeld-Realskoles Elevforening "Mine Forfædrehar boet under den herrnhutiske Tradition ", skriver han. "Endnu min Bedstefader, født i Tønder, en fremragende Skolelærer i Lindholm i det frisiske, byggede sit Opdragersyn paa den gamle: Lære. Men han var en mild og glad Mand. Hvor dette Syn parres med Alvor overfor Livets Ansvar, naas store Ting". - Han minder tillige om den tyske idealistiske Digter Schillers Verslinier i dennes Digt "Die Glocke«, en ophøjet Hyldest til det. religiøst indviede, Samfundet tjenende Borgerhaandværk, som. netop Herrnhuterne var de smukkeste Repræsentanter for:

"Denn wo das Strenge mit dem Zarten, Wo Starkes sich und Mildes paarten, Da gibt es einen guten Klang." 
Opdragelsen i Christiansfeld synes at have kunnet forene Strenghed og Mildhed paa en frugtbar Maade og har utvivlsomt med sit ligelige Hensyn til Aandens Gaver og Naturens Anlæg virket karakterdannende paa unge, modtagelige Sind, der kom ind under dens sollyse Indflydelse.

Herrnhutismens pædagogiske Linie er paa dansk Folkegrund fortsat i den grundtvigske Friskole og Højskole.

Sammenfattende tør det siges, at Kostskolen i Christiansfeld har ovet en historisk betydelig Gerning, som ikke mindst Nordslesvig har nydt godt af. Maa vi - set med danske Øjne - end klage over, at den har virket nationalt svækkende og til Fremme for Tyskheden i Granselandet, saa bør vi dog fremhæve med Anerkendelse, at den tillige har virket kristeligt bevarende og pædagogisk ansporende, hvilket ogsaa gennnem de skiftende Tider er kommet det danske Nordslesvig til Gode.7)

7) Rektor E. Tauber fremsætter i sine "Memoriae Coldingenses", trykte i "Haderslev-Samfundets Aarsskrift«, 1942, S. $15 \mathrm{ff}$, en ret afvisende Bedømmelse af Christiansfeld-Skolens religiøse og pædagogiske Betydning (omkring 1820). Han skriver bl. a.: "Væsenet drives her alt for overfladisk og fabelmæssigt .... Den udvortes Quindelighed dannes vel her til en Normaldyd, som synes frappant. Men adskillige Exempler have belært mig, hvor svagt disse afrettede Pupper bestaae mod Verdenslivets Fristelser. Det synes næsten, som den fyrige Ungdom, der udgaaer fra disse Klosterskoler, efter sin Indtrædelse $i$ den store Verden, alt for ofte vil holde sig skadeslas for det glædeløse Liv, hvori den saa sin Barndom hensvinde. Udelukkelse fra Livets uskyldige Glæder, paa en Tid, da Tilbøjelighederne saa stærk indbyde til disse, er naturstridig."

Denne efter Indhold og Ordvalg i høj Grad subjektive Karakteristik maa dog ses' paa Baggrund af Autorens fra Herrnhutismen vidt forskellige religiøse og pædagogiske Indstilling og kan ikke gælde som en historisk retfærdig Dom. Han var klassisk Humanist og religiøs Rationalist og synes ikke at have haft nogen Sans for det bærende evangeliske i Christiansfeld-Opdragelsen, hvilket ogsaa hele hans ovrige negative Syn paa Herrnhuterne som "skinhellige", "umoralske«, "intollerante», "pengegridske«, »drikfældige» m. v. tilstrækkeligt stadfæster. Han fabulerer i Tidens egen aandeligt overfladiske Stil og har - betegnende nok - kun faaet Øje paa sin Modparts »Orden og Reenlighed", "Flid' .... og Velstand", der dog skulde synes at tyde paa en renere Kilde end den af ham angivne. -

(I et kommende Hefte af "Sønderjydske Aarboger« vil der blive trykt en Fortegnelse over Christiansfeld-Skolens KostElever fra 1775 til 1891). 


\section{Utrykte Kilder.}

Sk o l e a r i vet i Christiansfeld, der bl. a. indeholder: Persoralielister (delvis meget ufuldstændige); Protokoller (1785-1805, 1835 -61); Prospekter (1774, ca. 1795, 1846; ca. 1872; 1882); Aarsoversigter (1852-90); Instruktioner (1836, 1864); Diarier (1882-91); Adressebog; Korrespondance (1799-1847); Forskelligt, bl. a. et værdifuldt Privathefte med Optegnelser om herrnhutisk Opdragelse, skrevet af en Forstanderinde i Pige-Skolen.

Deswarre har det for Tiden ikke voret muligt at fremskaffe et Billede af Skoleinspektor S. Sønnichsen.

For Imodekommenhed under Benyttelsen af Arkiumaterialet $i$ Christiansfeld, sil jeg gerne udtale min hjertelige Tak til Hr. Pastor Paul Fabricius ved Bradremenigheden $i$ Christiansfeld. 